\title{
Survey on corporate strategic planning systems in Zimbabwe
}

\author{
S. Shabalala
}

Department of Business Studies, University of Zimbabwe, Harare

The decision to undertake a preliminary survey on corporate strategic planning systems was motivated by the dearth of information of 'the state of the art' in the strategic management of companies within Zimbabwe. This state of affairs seriously affected the teaching of the Business Policy course within the Department of Business Studies: lack of local contextual information on how general managers play their roles as architects of company strategies, organization builders and leaders, robbed the teaching of Business Policy of its fundamental background.

It was the purpose of this survey to start the ball rolling by way of establishing meaningful relations between industry and the department of Business Studies, so as to facilitate the exchange of ideas and viewpoints. Such relations will, hopefully, develop the atmosphere of trust which will be crucial in enabling scholars to develop management cases, based on the Zimbabwean sociopoliticoeconomic environments. These cases will be used by students in the University and by others who run executive development programmes all over Zimbabwe.

As a preliminary survey, no major conclusions can be drawn from its findings. It has, however, opened up a direction for more thorough and sophisticated research in the future.

S. Afr. J. Bus. Mgmt. 1984, 15: $34-52$

Die besluit om 'n voorlopige opname van korporatiewe strategiese beplanningsisteme binne Zimbabwe te loods, was gemotiveer deur die absolute tekort aan inligting oor die stand van strategiese bestuursisteme van maatskappye in die land. Die toe stand het die opleiding van bestuursbeleid binne die Departement van Bestuurstudies negatief beïnvloed: die gebrek aan toepaslike inligting oor hoe hoofbestuurders hul rol as argitekte van strategie en organisasiebouers en -leiers speel, het die onderrig van Bestuursbeleid van ' $n$ vaste basis ontneem.

Dit was die doel van hierdie opname om 'n betekenisvolle kop pelvlak tussen die akademici en bedryfsleiers te vestig, en sodoende die uitruiling van idees en beskouinge in wisselwerking te bring. So 'n verhouding is natuurlik noodsaaklik om navorsers te help om gevallestudies te ontwikkel, wat die sosio-politieseekonomiese omgewing in Zimbabwe weerspieèl.

As 'n voorlopige opname, is alleen data ingew gevolgtrekkings kan van die is alleen data ingewin en geen groot egter dien as 'n basis wae bevindinge bekom word nie. Dit kan toekoms kan steun. S.Afr. Tydskr. Bedryfsl. 1984, 15: 34-52

\section{The research design}

The survey was conducted through the use of a 17-page questionnaire. A sample of $\mathbf{4 0}$ companies was selected basically on two criteria: size of turnover and membership of the Zimbabwe Stock Exchange. A covering letter, a copy of the questionnaire and a reply-paid envelope were mailed to each respondent company in the third week of February 1983.

Respondents were requested to describe the planning systems and processes of their companies as they truly existed, not as they believed they should exist.

The questionnaire was divided into four parts: Parts I, II and IV were to be completed by companies with formalized (written) strategic plans; parts III and IV were to be completed by companies with informal strategic planning systems.

Some questions in the questionnaire asked the respondent to choose one or a combination of answers among several possibilities, others asked the respondent to rank alternatives in terms of their relative importance to his or her company. The respondents were also asked to specify alternatives other than those provided. Questions on management information systems were open-ended. One questionnaire was returned because of an incorrect address and five others were returned unfilled, with various reasons given for doing so. There was no response from 16 companies: thus 18 companies constituted the sample for the survey.

Before analysing the questionnaire returns, the researcher conducted follow-up interviews with selected representatives of respondent companies. In the body of the report, percentage responses for questions requesting only a single answer are given out of the total sample, or, where the companies have been divided into two categories, out of the total number of companies with formal or informal strategic planning systems.

For questions requesting a ranking of possible responses, (' 1 ' referring to the most important, etc), the percentage responses for each possible answer, within each rank are reported.

In general, it was possible to test a number of possible null hypotheses: subsidiaries of multi-national companies formalize their strategic management systems more than 'indigenous' or local companies; companies with organization structures matching their growth strategies have higher financial performance than those with mismatches; companies with formalized strategic management systems (keeping industry constant) outperform those with informal systems, etc. The researcher, however, feels that the purpose of the survey was 'to get a feel of the state of the art'; sophisticated statistical analyses require larger samples and concentration in few areas at a time.

\section{S. Shabalada}

Department of Business Studies, University of Zimbabwe,

P.O. Box MP 167, Mt Pleasant, Harare, Zimbabwe 
Responses to some questions were also not usable in all areas of analytic interest. All these factors influenced the researcher not to deduce any statistical significance when testing in a number of possible areas.

\section{Introduction}

Strategic management and strategic decisions represent a company's chosen pattern of relating to its environment in pursuit of specified purposive ends: the chosen direction and pattern of relating to a relevant environment is characterized by mission and objectives statements; product/service-markettechnology choices; adoption of a particular mode of competition (to achieve a distinctive competence); and, patterns in resources mobilization and deployment.

Companies differ in the degree to which the formalization of strategic planning systems is achieved. For the purpose of this survey, and this is the approach taken in the teaching of Business Policy at the University of Zimbabwe, companies with formal strategic planning systems are distinguished from those with informal systems. The former group has, among other things, written short to long-term company plans, formalized planning cycles and responsibilities, budgetary systems which are formalized and used as yearly implementary mechanisms for strategic plans, etc. In the latter category, the strategic behaviour of such companies is determined through the diagnosis of the pattern of persistent decisions, having to do with choices in the following areas: product/service-markettechnology, mode of competition, resources deployment and self-concepts of top management as detected from major policy statements and declarations of personal values, which include an expression of internalized sense of social responsibility.

In this survey the researcher takes the view that the strategic management system is all-embracing of all management processes or systems that have to do with relating the company to its environment while, at the same time, satisfying the changing needs of its active members. Strategic planning or longrange planning is but an integral part of strategic management processes - it is a backbone support to strategic management (Steiner, 1979). In planning, a company designs a desired future and identifies ways and means to bring it about.

\section{Discussion}

In discussing the responses to this survey the following sequence of treatment will be used: Firstly, the issues and research undertaken in other areas are given; secondly, the findings of the Zimbabwe study follow; and thirdly, the implications and lessons arising from the issues and research findings will close the discussion under each sub-topical area.

\section{Formalization of strategy planning processes}

\section{Precipitating events}

\section{Issues}

The experience from private enterprise economies is that, for ongoing companies, the formalization of strategic planning processes is precipitated by certain events. Organizations' 'ways of doing things' represent frozen past 'memories', born of past precedents, which are not usually abandoned without hesitations and resistance. This, therefore, means that for companies that have been following informal strategic planning processes, there needs to be a strong precipitating impetus to move managerial inertia to new and demanding formalized strategic planning practices and processes.
Table 1 Events leading to strategic planning formalization

\begin{tabular}{lc}
\hline Events & $\begin{array}{c}\text { Percentage } \\
\text { response }\end{array}$ \\
\hline Change in company ownership & 20 \\
New top executive(s) & 40 \\
Competitive threats & 20 \\
Competitive opportunities & 20 \\
Technological innovation & 0 \\
Supplies constraints & 10 \\
Socio-politico-economic uncertainties & 50 \\
Others (specify) & \\
- reorganization & 30 \\
- introduction of MBO & 10 \\
\hline
\end{tabular}

\section{Findings in Zimbabwe}

Table 1 , in this report, shows the percentage responses by respondent companies to factors which precipitated the formalization of strategic planning processes. The leading precipitating event is the growing socio-politico-economic uncertainties $(50 \%)$, followed by the arrival of new top executive(s) and the reorganization of the companies $(30 \%)$. The third ranked factors which contributed to the formalization of strategic planning processes, given by $20 \%$ of the respondent companies were: changes in company ownership, competitive opportunities and threats.

Factors contributing to successful formalization of strategic planning processes

Issues

It is conceivable that, at any given time, two or more companies may be exposed to or perceive the presence and impact of similar precipitating event(s). The perception and responses to such event(s) do not inexorably lead to the formalization of strategic planning processes. Why is it so? The answer is that there need to be some background factors whose presence or absence determines whether or not formalization would take place.

\section{Findings in Zimbabwe}

A list of potential factors which might contribute toward the formalization of strategic planning processes is given in Table 2 . Responses to these potential factors were ranked. The highest ranked factor by $60 \%$ of the respondent companies was Management Style. Following Management Style were: Control Over Strategic Factors (30\%), Company Culture (20\%) and Management Capabilities (20\%).

Table 2 Contributory factors to successful introduction of formal strategic planning

\begin{tabular}{|c|c|c|c|c|c|c|c|c|c|}
\hline \multirow[b]{2}{*}{ - Company's culture } & \multicolumn{9}{|c|}{ Percentage assigning rank } \\
\hline & 10 & 20 & 20 & 10 & 10 & $\mathbf{0}$ & 10 & 0 & 10 \\
\hline - Management style & 60 & 10 & 20 & 10 & 0 & 0 & 0 & 0 & 0 \\
\hline - Time horizon & 0 & 10 & 10 & 20 & 10 & 20 & 30 & 0 & $\mathbf{0}$ \\
\hline - Control over strategic factors & 0 & 30 & 10 & 50 & 10 & $\mathbf{0}$ & 0 & 0 & 0 \\
\hline $\begin{array}{l}\text { Information processing } \\
\text { capabilities }\end{array}$ & & 10 & 20 & $\mathbf{3 0}$ & 30 & 10 & 0 & $\mathbf{0}$ & $\mathbf{0}$ \\
\hline $\begin{array}{l}\text { - Management compensation } \\
\text { systems }\end{array}$ & 0 & $\mathbf{0}$ & 0 & 10 & 20 & 20 & 30 & 20 & 0 \\
\hline - Management capabilities & 10 & 20 & 10 & 0 & 20 & 20 & 10 & 0 & 0 \\
\hline - Orher (specify) & 0 & 0 & 0 & 0 & 0 & 0 & 0 & 0 & 0 \\
\hline
\end{tabular}




\section{Resistance to the formalization of strategic planning processes}

Issues

The introduction of a successfully formalized and effective strategic planning process is usually resisted. Resistance operates at two levels: Overt resistance may prevent the formalization of strategic planning processes, especially when such resistance is associated with the influentials of the company; there might be concurrence with change (formalization), but this might be accompanied by sloppy work, sabotage of certain tasks, endless conflicts among peers in the company, etc.

\section{Findings in Zimbabwe}

Table 3 shows ranked responses to reasons behind resistance to the formalization of strategic planning processes in sampled companies in Zimbabwe. Thirty percent of the respondents gave the highest rank to the perception that formalized strategic planning processes demand know-how not possessed by respondent companies. Differences in perceived risks by different incumbents in managerial positions were ranked second by $40 \%$ of the participating companies. James Quinn (1980) states that 'perceived risk is largely a function of one's knowledge about a field'. With this description of a risk paradigm, it is clear that the first and second ranked reasons behind resistance to the formalization of strategic planning processes are closely related. Still within the second rank, $20 \%$ of the respondents gave the following reasons: Perceived less participation in important decisions affecting incumbents careers, and Potential/actual reduction in previously allocated resources. Perceived loss of power/control by incumbents was ranked third by $40 \%$ of the participating companies.

Companies which have not formalized their strategic planning processes agreed, in the order of significance, to the following reasons for not doing so:

(i) Top management perceives no advantage in formalizing strategic planning activities.

(ii) The company's external environment is too complex and dynamic that there would be little benefit in formalizing strategic planning activities.

(iii) The company's line managers feel that formalized strategic planning activities introduce rigidity in the strategic management processes of companies.

The extent of the formalization of strategic planning activities between 'indigenous' Zimbabwean companies and locally registered subsidiaries of multinational companies is given

Table 3 Resistance to the formalization of strategic planning

\begin{tabular}{|c|c|c|c|c|c|c|c|c|c|}
\hline \multirow[t]{2}{*}{ Reasons for resistance } & \multicolumn{9}{|c|}{ Percentage assigning rank } \\
\hline & 1 & 2 & 3 & 4 & 5 & 6 & 7 & 8 & 9 \\
\hline - Differences in perceived risks & 10 & 10 & 10 & 20 & 0 & 0 & 0 & 0 & 0 \\
\hline - Perceived less participation & 10 & 20 & 10 & 20 & 20 & 0 & 0 & 0 & 0 \\
\hline - Short tenure of top executive & 0 & 10 & 20 & 10 & 10 & 0 & 10 & 10 & 0 \\
\hline $\begin{array}{l}\text { - Loss of importance (hence } \\
\text { power) of certain product(s), } \\
\text { divisions, functions }\end{array}$ & 10 & 10 & 20 & 30 & 10 & 0 & 0 & 0 & 0 \\
\hline $\begin{array}{l}\text { - Potential/actual reduction } \\
\text { of previously allocated resources }\end{array}$ & 0 & 20 & 10 & 10 & 10 & 0 & 30 & 0 & 0 \\
\hline $\begin{array}{l}\text { - Affected promotability of } \\
\text { certain managers }\end{array}$ & 0 & 10 & 10 & 10 & 10 & 20 & 30 & 0 & 0 \\
\hline - Demanded new know-how & 30 & 20 & 0 & 0 & 0 & 0 & 20 & 30 & \\
\hline
\end{tabular}

Table 4 Company ownership and the formalization of strategic planning

\begin{tabular}{lcc}
\hline Company ownership & $\begin{array}{c}\text { Percentage } \\
\text { formalized }\end{array}$ & $\begin{array}{c}\text { percentage not } \\
\text { formalized }\end{array}$ \\
\hline Subsidiaries of foreign & 87 & 13 \\
Companies & 30 & 70 \\
\hline Zimbabwean companies & & \\
\hline
\end{tabular}

in Table 4. Eighty-seven percent of subsidiaries of multinationals have formalized strategic planning activities compared to $30 \%$ of 'indigenous' Zimbabwean companies.

\section{Implications and lessons}

The occurrence of a 'felt need' to formalize strategic planning systems and their successful introduction is affected by a number of factors. Moving an organization from its informal to formal strategic behaviour is dependent on two factors: there should be a consensual perception of the events which signal a need to formalize strategic planning activities; the presence of a change agent with sufficient positional and expert power, and high interpersonal skills.

Resistance to changes in an organization's 'old way of doing things' is a natural phenomenon. This resistance should be managed. Since novelty, complexity, open-endedness and dealing not only with unpredictable but also with ambiguous conditions characterize strategic-making processes (Mintzberg $e t$ al., 1976), the formalization of strategic planning systems increases the perception of risks and fear of failure. Furthermore, the formalization of strategic planning systems brings about changes in interpersonnel relationships, information flows, power relationships, etc. (Steiner, 1979). The upshot of the exposition here is that, under formalized strategic planning systems, objectives tend to be more specific, allocation of responsibilities is more precise, and the standards for performance evaluation of units and their incumbents are generally clearcut. There is, in general, little room for hiding incompetences in strategy formulation and implementation.

At this point a caveat is necessary: the formalization of strategic planning is not, by itself, a panacea for all the problems normally faced by management; it does not eliminate risk or uncertainty, but it allows the company to deal with uncertainty systematically. 'The more uncertain the future in fact, the more necessary it is to contemplate what can happen and what is likely to happen, and to assign probabilities to the imaginable possibilities' (Andrews, 1971).

Over dedication to a plan to the point of losing sight of unexpected opportunities should be avoided. The concept of strategic issues management (Ansoff, 1980) requires that the company should maintain a moving balance based on the consideration on which its strategy is based, and should continually maintain a match between its resources and the opportunities in its environment. To adhere to a plan, 'blindly when changing circumstances has made it obsolete is no more preferable than thoughtless opportunism' (Andrews, 1971).

In summary, it should be appreciated that under conditions of growing business competitiveness, complexity of sociopolitico-economic environments and decreasing business resources, the formalization of strategic planning processes enhances the adaptive and integrative capabilities of companies.

Wheelright and Bank (1979) identify five stages through which companies pass in the formalization of their strategic planning systems. These stages are: preplanning (informal plan- 
ning), initial development, intermediate development, advanced /comprehensive and, lastly, the advanced/simplified stage.

These stages are characterized by the initial dependence on outside consultants or excessive use of planning staff with little involvement of middle-to-lower line managers in the planning processes; the move from largely financially based, numbers-oriented planning processes to increased emphasis on conceptual and strategic issues; the major involvement of line managers to planning processes; and lastly, the use of planning systems as bases for decisions and performance evaluation.

In going through these stages there are a number of pitfalls to be avoided: quick moves through stages with ill-prepared organizational elements (management, expertise, information, acceptability, etc.) can prove disastrous; so is the temptation to come out with elaborate planning systems. Leap-frogging some stages and failure to modify, where desirable, the planning processes and procedures finally undermine the efficacy of formalized strategic planning processes (Wheelright and Bank, 1979).

\section{Planning responsibilities}

Issues

Effective strategic planning requires: top management commitment to it; full participation by line managers with responsibilities to provide informational inputs to the planning process and those who implement and monitor planned programmes; the availability of reliable and timely information; and, the correct use of the corporate planning staff (if any).

Environmental assessment and broad corporate objectives determination, in the light of the company's strengths and weaknesses, represent the 'front-end' of the planning process. The review and the evaluation of planned programmes represent the 'back-end' and its link with the 'front-end' of the planning process characterize the adaptation posture of the company (Lorange, 1980).

The integration needs of the company are achieved through strategy implementation activities which translate plans into specifically scheduled programmes; assign specific responsibilities, authority; and, allocate requisite resources to different units of the company.

Top management (Chief Executive, Corporate Top Management, Group Management, etc.) plays a major role in providing planning parameters through the setting of broad objectives based on the assessed planning premises. The expected performance of the operating divisions/functions is also spelt out. After receiving detailed divisional/functional plans (with accompanying detailed budgets) top management assess consistency, feasibility and adequacy of such plans before allocating corporate resources to different company units. The desired output of the planning cycle is to achieve or enhance the company's adaptive capability without sacrificing integration requirements for the company as an economizing system.

\section{Findings in Zimbabwe}

Broad planning responsibilities from sampled Zimbabwean companies are given in Table 5a. Sixty percent of the respondent companies reported that the determination of corporate objectives is the responsibility of Top Management (Top Corporate/Group Top Management).

The allocation of corporate resources is reported by 50 and $80 \%$ of the respondent companies to be the responsibility of the Corporate Top Management and Group Management respectively. It should be noted that in some companies the two management levels are considered to be the same, i.e. are
Table 5a Broad distribution of planning responsibilities - Hierarchical level

\begin{tabular}{|c|c|c|c|c|c|c|}
\hline Planning activity & C.T.M & G.T.M. & C.P.S. & R.L.M. & R.M.: & Other \\
\hline & $\%$ & $\%$ & $\%$ & $\%$ & $\%$ & $\%$ \\
\hline $\begin{array}{l}\text { Determination of corporate } \\
\text { objectives }\end{array}$ & 60 & 60 & 10 & 0 & 0 & 0 \\
\hline $\begin{array}{l}\text { Product/service/market } \\
\text { choices(s) }\end{array}$ & 40 & 40 & 10 & 50 & 10 & 0 \\
\hline $\begin{array}{l}\text { Corporate mode of compe- } \\
\text { tition }\end{array}$ & 70 & 60 & 0 & 30 & 0 & 0 \\
\hline $\begin{array}{l}\text { Business/divisional mode } \\
\text { of competition }\end{array}$ & 20 & 50 & 0 & 60 & 10 & D \\
\hline $\begin{array}{l}\text { Allocation of corporate } \\
\text { resources }\end{array}$ & 50 & 80 & 0 & 0 & 0 & 0 \\
\hline $\begin{array}{l}\text { Business/divisional/products } \\
\text { synergies }\end{array}$ & 40 & 60 & 0 & 60 & 20 & 0 \\
\hline
\end{tabular}

C.T.M. = Corporate top management; G.T.M. = Group top management C.P.S. = Corporate planning staff; R.L.M. = Responsible line managernent R.F.L.M. = Responsible functional line management.

composed of the same persons.

Business/divisional modes of competition are delegated to Responsible Functional Management (60\%). Group Top Management participates in the determination of business/ divisional modes of competition in $50 \%$ of the respondent companies. Product/Service-market choices are reported to be the responsibility of Responsible Functional Managers and Group Top Management in 50 and $40 \%$ of the respondent companies respectively.

More detailed planning responsibilities are shown in Table 5b. The Group Top Management and Division Management levels are more involved in corporate objectives setting, with the Corporate Planning Staff more concerned with organizing and co-ordinating planning efforts. The assessment of company strengths and weaknesses appears to be spread down the management hierarchy, with the Group Top Management playing a major role. The Divisional and Functional levels have, as their delegated responsibility, the evaluation of competitive environments and their plans are integrated at divisional levels. Lastly, the allocation of corporate resources and the review of the effectiveness of plans are the responsibility of Top Management.

\section{Implications and lessons}

The responses of the reporting companies demonstrate that planning activities are adequately spread or delegated to relevant responsibility centres. What top management should strive to achieve is a proper top-down and bottom-up balance in the planning processes.

The bottom-up emphasis (lower management/unit levels having a strong initiating and strong responsibility in planning processes) is likely to yield strong business, divisional, etc. adaptive capabilities. The exploitation of internal growth opportunities and the tackling of potential threats from competitive environments can be better achieved within a bottom-up emphasis.

As in most managerial and/or organizational activities, too much bottom-up emphasis may produce dysfunctional effects in diversified business/product portfolios. 'Balanced growth in sales, earnings, and asset mix at an acceptable and controlled level of risk' may be sacrified where divisions, strategic business units or product managers pursue their sectarian interests with disregard to the overall corporate strategy (Hall, 1978).

A relatively top-down emphasis (top corporate management 
Table 5b Distribution of planning responsibilities (Detail)

\begin{tabular}{|c|c|c|c|c|c|c|c|c|c|c|c|c|c|c|c|c|c|c|c|c|c|}
\hline \multirow[b]{3}{*}{ Planning activity } & \multicolumn{21}{|c|}{ Strategic planning responsibilities } \\
\hline & \multicolumn{3}{|c|}{ T. $\mathbf{M g t}$} & \multicolumn{3}{|c|}{ C.P.S. } & \multicolumn{3}{|c|}{ G.M.L. } & \multicolumn{3}{|c|}{ D.M. } & \multicolumn{3}{|c|}{ D.P.S. } & \multirow[b]{2}{*}{$\mathbf{v}$} & \multicolumn{2}{|c|}{ I.P.G. } & \multicolumn{3}{|c|}{ F.M. } \\
\hline & $\mathbf{v}$ & $\mathbf{x}$ & $\mathbf{O}$ & $\mathbf{v}$ & $\mathbf{x}$ & $\mathrm{O}$ & $\mathbf{v}$ & $\mathbf{x}$ & $\mathbf{0}$ & $\mathbf{v}$ & $\mathbf{x}$ & $\mathbf{0}$ & V & $\mathbf{x}$ & $\mathbf{O}$ & & $\mathbf{x}$ & $\mathbf{O}$ & $\mathbf{v}$ & $\mathrm{x}$ & 0 \\
\hline & & $\%$ & & & $\%$ & & & $\%$ & & & $\%$ & & & $\%$ & & & $\%$ & & & $\%$ & \\
\hline $\begin{array}{l}\text { Formulate corporate objec- } \\
\text { tives }\end{array}$ & 70 & 10 & 40 & $\mathbf{0}$ & 30 & 30 & 10 & 50 & 20 & $\infty$ & 60 & 0 & $\mathbf{0}$ & 0 & 0 & 0 & 0 & $\mathbf{0}$ & 0 & 10 & $\mathbf{0}$ \\
\hline Set planning horizons & 70 & 10 & 30 & $\mathbf{0}$ & 10 & 0 & 0 & 20 & 0 & 10 & 0 & 0 & 0 & $\mathbf{0}$ & 0 & $\mathbf{0}$ & 0 & 0 & 0 & 0 & 0 \\
\hline $\begin{array}{l}\text { Organize \& Co-ordinate } \\
\text { planning effort }\end{array}$ & 10 & 10 & 10 & 10 & 30 & 20 & 20 & 20 & 10 & 20 & 0 & 0 & $\mathbf{0}$ & 0 & 10 & $\mathbf{0}$ & 0 & 10 & 0 & 10 & 0 \\
\hline Forecast sales & 50 & 0 & 20 & $\mathbf{0}$ & 11 & 10 & 10 & 10 & 20 & 30 & 10 & 0 & 0 & $\mathbf{0}$ & 20 & $\mathbf{0}$ & 0 & $\mathbf{0}$ & 0 & 50 & $\mathbf{0}$ \\
\hline $\begin{array}{l}\text { Assess company's strengths } \\
\text { and weaknesses }\end{array}$ & 40 & 20 & 0 & $\mathbf{0}$ & 20 & 0 & 20 & 30 & 40 & 20 & 10 & 0 & 0 & 0 & 10 . & $\mathbf{0}$ & 0 & 0 & 0 & 20 & 0 \\
\hline $\begin{array}{l}\text { Evaluate competitive } \\
\text { environments }\end{array}$ & 30 & 0 & 20 & 0 & 10 & 11 & 10 & 40 & 40 & 60 & 10 & 0 & 0 & 0 & 10 & 0 & 0 & 0 & 0 & 30 & 0 \\
\hline $\begin{array}{l}\text { Establish divisional/business } \\
\text { objectives }\end{array}$ & 70 & 10 & 20 & 0 & 20 & 20 & 10 & 40 & 30 & 50 & 0 & 0 & 0 & 0 & 20 & 0 & 0 & 0 & 0 & 30 & 0 \\
\hline $\begin{array}{l}\text { Formulate alternative divi- } \\
\text { sional/business strategies }\end{array}$ & 50 & 0 & 10 & 0 & 10 & 10 & 10 & 20 & 30 & 60 & 0 & 0 & 0 & 0 & 10 & 0 & 0 & 0 & 0 & 10 & 0 \\
\hline $\begin{array}{l}\text { Select preferred divisional/ } \\
\text { business strategies }\end{array}$ & 50 & 0 & 10 & 0 & 10 & 10 & 10 & 20 & 20 & 60 & 0 & 0 & 0 & 0 & 10 & 0 & 0 & 0 & 0 & 10 & 0 \\
\hline $\begin{array}{l}\text { Select preferred divisional/ } \\
\text { business projects }\end{array}$ & 50 & 0 & 10 & 0 & 20 & 0 & 20 & 20 & 20 & 50 & 0 & 0 & 0 & 0 & 0 & 0 & 0 & 0 & 0 & 30 & 0 \\
\hline $\begin{array}{l}\text { Formulate functional } \\
\text { objectives }\end{array}$ & 40 & 0 & 0 & 0 & 0 & 10 & 20 & 10 & 30 & 20 & 30 & 0 & 0 & 0 & 10 & 0 & 0 & 0 & 0 & 50 & 0 \\
\hline
\end{tabular}

Table 5b (continued)

\begin{tabular}{|c|c|c|c|c|c|c|c|c|c|c|c|c|c|c|c|c|c|c|c|c|c|}
\hline \multirow[b]{3}{*}{ Planning activity } & \multicolumn{21}{|c|}{ Strategic planning responsibilities } \\
\hline & \multicolumn{3}{|c|}{ T. Mgt } & \multicolumn{3}{|c|}{ C.P.S. } & \multicolumn{3}{|c|}{ G.M.L. } & \multicolumn{3}{|c|}{ D.M. } & \multicolumn{3}{|c|}{ D.P.S. } & \multicolumn{3}{|c|}{ I.P.G. } & \multicolumn{3}{|c|}{ F.M. } \\
\hline & v & $\mathbf{x}$ & 0 & $\mathbf{v}$ & $\mathbf{X}$ & 0 & $\mathbf{v}$ & $\mathbf{X}$ & 0 & $v$ & $\mathbf{x}$ & o & v & $x$ & o & V & $x$ & o & V & $\mathrm{x}$ & O \\
\hline & & $\%$ & & & $\%$ & & & $\%$ & & & $\%$ & & & $\%$ & & & $\%$ & & & $\%$ & \\
\hline $\begin{array}{l}\text { Establish functional strategic- } \\
\text { programmes }\end{array}$ & 40 & 0 & 0 & 0 & 0 & 0 & 10 & 10 & 30 & 30 & 20 & 0 & 0 & $\mathbf{0}$ & 10 & 0 & $\mathbf{0}$ & 0 & 0 & 50 & 0 \\
\hline $\begin{array}{l}\text { Integrate divisional/func- } \\
\text { tional plans }\end{array}$ & 70 & 0 & 20 & 0 & 20 & 20 & 10 & 20 & 30 & 40 & 0 & 0 & 0 & 0 & 10 & 0 & $\mathbf{0}$ & 0 & 0 & 30 & $\mathbf{0}$ \\
\hline Allocate corporate resources & 70 & 30 & 20 & 0 & 10 & 20 & 10 & 30 & 2 & 10 & 10 & 0 & $\mathbf{0}$ & 0 & 0 & $\mathbf{0}$ & $\mathbf{0}$ & 0 & 0 & 0 & 0 \\
\hline Review progress against plans & 30 & 20 & 20 & $\mathbf{0}$ & 20 & 30 & $\mathbf{0}$ & 20 & 20 & 40 & 20 & 0 & 0 & 0 & 10 & 0 & 0 & 0 & 0 & 0 & 0 \\
\hline Evaluate plans effectiveness & 30 & 30 & 30 & $\mathbf{0}$ & 20 & 30 & 0 & 20 & 20 & 30 & 20 & 0 & $\mathbf{0}$ & 0 & 0 & $\mathbf{0}$ & $\mathbf{0}$ & 0 & 0 & 0 & 0 \\
\hline
\end{tabular}

$\checkmark$ - approves

$X$ - Does the work

O - Reviews, evaluates \& counsel

\author{
T. Mgt = Top management \\ C.P.S. = Corporate planning staff \\ G.M.L. = Group management level
}

D.M. = Divisional management

D.P.S. = Divisional planning staff

I.P.G. = Intermediary planning group (specify)

F.M. = Functional management playing major roles in planning processes) in diversified companies has, as its effect, the strengthening of the integrative planning capabilities with respect to the corporation's ongoing businesses (Lorange, 1980). A zealous pursuit of integration sacrifices the timely responsiveness of the diverse business units to differentiated product/service-market-technology environmental changes.

The emphasis from the discussion above is that a proper top-down and bottom-up balance in the strategic management behaviour of a company helps in enhancing its adaptive capability without sacrificing the need for the company to move or adapt to the challenges and opportunities of its environments as an integrated whole.

\section{Information system \\ Issues}

The management information system (MIS) is an integral part of a company's strategic management system. It is incorrect to take MIS merely as a support system to strategic planning. The entire strategic management processes involve information gathering, processing and interpretation: environmental assessment, statement of strategy assumptions and the setting of objectives; strengths and weaknesses analysis; 'What if?' sensitivity analysis; and, strategic programmes implementation and reviews depend on the MIS.

The formalization of strategic planning activities goes handin-hand with the formalization of MIS which must reflect the structure, content and processes of the chosen strategic planning system. The effectiveness of any strategic planning system is, undoubtedly, dependent on the quality and quantity of available information.

\section{Findings in Zimbabwe}

Looking at the Zimbabwean scene, as represented by responses from the respondent companies, few observations are worth highlighting. Only $40 \%$ of companies with formal planning systems have computerized MIS.

Tables $6 \mathrm{a}$ and $6 \mathrm{~b}$ show composite internally and externally generated information respectively. The presented information is used during strategic planning processes. The lists appear long: this is misleading. Taking the list showing internally generated information first, only Competitor Analysis and 
Table 6a Internally generated information

\begin{tabular}{ll}
\hline - Macro economic ass. (3 year & - Graphs \\
forecast) & - Statistics \\
- Micro assumptions e.g. \% & - Market research \\
wage increase & - Sales estimate \\
- Economic analysis & - Budgets \\
- Political analysis & - Board minutes \\
- Market share & - Planning committee minutes \\
- Competitor analysis & - Specific reports \\
- Business mix & - Capital expenditure require- \\
- Market trends & ments \\
- Overhead cost trends & - Credit facility requirements \\
- Monthly and annual accounts & - Manpower requirements \\
\hline
\end{tabular}

Table 6b Externally general information

\begin{tabular}{ll}
\hline $\begin{array}{l}\text { Official statistics (monthly } \\
\text { digest of statistics) }\end{array}$ & - Government three year plan \\
- Local and international eco- & - journancial newspapers and \\
nomic trends (Economic & - Economic \\
report) & - Relative legislation \\
- Foreign exchange availability & - Historic macro economic data \\
- Bank economic reports & - Metal market forecasts \\
- Reserve bank quarterly & - Press statements \\
reports & - Economic reviews \\
- Growth with equity (Govern- \\
$\begin{array}{l}\text { ment and Economic policy } \\
\text { statements) }\end{array}$
\end{tabular}

Market Research were reported by three companies. Sales Estimates were reported by only two companies. The remaining information items in the list were reported by single companies. Table $6 \mathrm{~b}$ shows information items which are externally generated by the respondent companies. Even here only official statistics (e.g. Monthly digest of statistics) were reported by three companies. Bank economic reports, and information from Financial newspapers and journals were each reported by two companies.

\section{Implications and lessons}

It is not clear whether the respondent companies considered the information area as confidential. Assuming this to be not the case, the conclusion to be drawn is that there is poor information management and availability among the respondent companies. It is a universal truth that, short of windfall luck, sloppiness in information availability translates itself to poor strategic planning processes, which results in poor strategic plans.

The MIS has to be designed around the company's organization structure and responsibility centres. It should reflect the level of autonomy as well as interdependence among responsibility centres within the company. For instance, a multidivisional company, with each division consisting of several businesses producing multiple products, requires a MIS with a hierarchy of Data Bases reflecting the following levels: Corporate, Group, Division, Business and Product (Naylor, 1979).

A hierarchy of responsibility units leads to a hierarchy of strategic plans, which should have, as their integral part, hierarchical Strategic Data Bases. It is highly recommended that business firms in Zimbabwe should make a conscientious effort to develop effective Strategic Data Bases in order to enhance their MIS. Any Strategic Data Base must reflect the environmental opportunities and risks facing a particular company as a whole; it should be decomposed to take diverse subenvironments facing each company's units/products/service(s). Competitive profiles (number of competitors, strengths and weaknesses of competitors, performance of company's product(s)/Service(s) against those of competitors at the market place, market shares, etc.) should feature prominently. Customer/user profiles, constraining or facilitating regulatory and socio-economic factors should be monitored and updated continually. The strategic inputs (raw materials, manpower, finance, equipment, etc.) availability, together with inputs markets behaviour should feature well in any company's MIS.

It is also important to include, within a company's MIS, its objectively determined strengths and weaknesses, including management viewpoints and values.

In concluding this section of the report, the three main roles of Strategic Data Base (which is part of MIS) can be given as follows:

(a) The enhancement of company's proactive adaptiveness.

(b) The formalization of middle management participation in strategic thinking processes.

(c) The provision of the training ground for the development of 'strategic thinking abilities which are so necessary for successful top-level management' (King \& Cleland 1975).

\section{Analytical tools used in strategic planning processes Issues}

Business firms have a number of analytical tools available to them for use in strategic management processes. These tools are used in areas like performance evaluation of Product/ Strategic Business Units (SBU) based on past/current strategies; in environment/industry analysis; and, in the identification of feasible strategies. Any level of efficacy achievable through the use of such strategy analytical tools as shown in Table 7 depends on: realistic assumptions about intra-business units behaviour; the business-environment interactive behaviour; the quality and quantity of information available to the users; and, the ability of the users, especially in the understanding of the strengths and weaknesses of each tool with its associated implicit and explicit assumptions.

\section{Findings in Zimbabwe}

Table 7 shows the types and levels of use of different tools by the respondent companies. The most popular analytical

\section{Table 7 Analytical tools used in strategic planning}

\begin{tabular}{lc}
\hline Tool used & Percentage response \\
\hline Product/market life cycle & 60 \\
Business/market portfolio analysis & 90 \\
Market attractiveness - business competitive & \\
position & 80 \\
Learning curve analysis & 30 \\
Experience curve analysis & 0 \\
Environmental forecasting techniques & 70 \\
Econometric forecasting & 40 \\
Regression analysis & 10 \\
Sensitivity analysis & 40 \\
Other (specify) & 0 \\
\hline
\end{tabular}


tools used, in the order of importance, are:

(a) Business/Market Portfolio (90\%).

(b) Market Attractiveness-Business Competitive Position $(80 \%)$.

(c) Environmental Forecasting (70\%).

(d) Product/Market Life Cycles $(60 \%)$.

The Experience and Learning Curves Effects are surprisingly not used even though the first two tools have explicit and/or implicit assumptions based on them.

\section{Implications and lessons}

\section{Experience curve/market share connection}

The Experience effect phenomenon simply represents a situation whereby costs fall with cumulative production to date. Doubling the cumulative production volume of a company leads to a fall in 'total value - added costs - including administration, sales, marketing, distribution, etc. in addition to manufacturing costs'. These costs fall by a constant and predictable percentage (Boston Consulting Group (BCG), 1972; Abell \& Hammond, 1972; Chevalier, 1972).

Specifically, experiments conducted by the Boston Consulting Group led to the finding that value-added costs tended to decrease by 20 to $30 \%$ each time accumulated production doubles (BCG, 1968-1970).

The strategic implication of the Experience Effect is that the lowering of costs due to accumulated volume of production to date leads to higher profits to a firm selling its products at a going market price. It is for this reason that the Experience Effect is closely associated with market share, given that a relatively high market share implies a relatively high volume of production. Where this specifically applies, profitability can be taken to be a function of market share due to Experience Effect (Lorange, 1980).

For the Experience Effect tool to operate for the benefit of any company, it should be used wisely. The user should be satisfied that the market characteristics (size, rate of growth, life cycle, competitors' Experience Curves, etc.) and behaviour of present and future company costs meet the operating assumptions of the tool. As a strategic recommendation, one can say that where total costs reduce as a function of accumulated volume of production, a company should pursue a strategy geared to accumulate experience further than its competitors.

Furthermore, the effective use of the Experience Effect tool requires that a company should not only know its market share but, more importantly, its relative market share. The relative market share (which is expressed in the form of a market share coefficient) is a ratio of the company's market share to that of the market or market segment leader. Sometimes the share of the two or three leading companies in the market or market segment is used.

The concepts of market share and relative market share are very important. A company may be increasing its market share but at the same time be losing its relative market share. Or, on the other hand, a company may be maintaining its relative market share but losing its market share. In the former case, it is possible that the company might still be profitable as compared to a company or companies buying relative shares through heavy investment. In the latter situation the company would be losing to smaller companies which are increasing their shares, but is still profitable since it 'is staying under the large market shareholders' umbrella' (Chevalier, 1972). A company that is losing both its relative market share and its market share is in fact losing its entire competitive position (Chevalier, 1972).
To the would-be-empire-builders, Chevalier's (1972) caveat is pertinent at this point: the overall size of the company matters very little, but size in a given market segment represents where the name of the game is.

A company should carefully identify its market segment(s) for its product(s) and the cost structures associated with the identified market segments. Without similarities of costs structures in different market segments, it is difficult to compare size (accumulated production to date) and profitability.

Abell and Hammond (1979) provide other useful insights to the strategies based on Experience or Scale. The use of such strategies represents the 'selection of cost-price efficiency over non cost-price marketing effectiveness'. In market situations whereby customers or product users are 'more concerned with product and service features and up-to-date technology, a firm pursuing efficiency can find itself offering a low priced product that few customers want'.

In concluding the implications and lessons associated with the Experience Effect two points should be emphasized:

(a) The benefits accruing to a company using strategies suggested by the Experience Effect do not come about as a result of an inexorable law of market behaviour. The Experience Effect should be managed to be of use.

(b) Very few of the respondent companies know their market shares and from public statements of businessmen in this country, profitability is predominantly sought through the increase of product/services prices. This is a very narrow approach to profitability management. In fact, pursuing this option is disastrous for the long-term health of the Zimbabwe economy. It also destroys the development of an imaginative managerial cadre in this country.

Profitability can be maintained or increased through a number of options such as the:

(i) Reduction of costs as a function of accumulated volume of production.

(ii) Effective management of company inputs and throughputs.

(iii) Effective utilization of human resources (learning curve effects).

(iv) Utilization of the right technology - not necessarily sophisticated technology.

(v) Exploitation of local inputs and/or effective costs - conscious purchasing systems.

(vi) Lowering of unnecessary administrative overheads (expensive offices, expensive managerial perquisites, etc.).

(vii) Effective and efficient physical distribution system.

(viii) Demand stimulating pricing and credit policies, etc.

\section{Product business-market portfolio and market attraction-} business competitive position analytical tools

The effective utilization of the above tools is crucially dependent on the quality and quantity of information available to the company. Firstly, the company should correctly identify a relevant level of analysis (Product/Service, SBU, etc.). Secondly, the definition of market or market segment(s) served by a particular product/service or SBU is also important. Having successfully gone through the two steps above, the company is in a better position to answer the key strategic question: What does it take to be successful in this particular market or market segment?

It should be understood that Product/Business Market Portfolio analysis is keyed around market share (given its assumed relationship with profitability and cash flows), size and market growth rate, (which is related to Product/Business Life Cycle 
and Market Attractiveness) (Abell \& Hammond 1979). The user of the typical SBU Portfolio analysis has to be aware that a number of factors are not easily captured within the Portfolio displays and analysis. Abell and Hammond (1979) provide these missing factors: barriers to entry; technological changes; social, legal, political and environmental pressures; unions and related human factors; management capabilities; cyclicality of sales, rate of capital utilization; responsiveness of sales to changes in prices, promotion, etc.

There are two major factors which influence the relative attractiveness in investing in a particular product/business unit. These factors fall within: Company environment (market/industry growth rate, levels of profit margins, levels of regulation, competitors capabilities, etc.), and the company's strengths and weaknesses (manufacturing costs, research and development capabilities, market share enjoyed, responsiveness of the company to opportunities and risks, etc.).

In strategic terms, the company should be so positioned as to exploit whatever opportunities that avail themselves or can be created; and, it should be capable of minimizing or eliminating the crippling effects of its environmental threats.

In conclusion, the reader should be reminded that even though the successful use of the above strategy analytical tools is circumscribed by the quality and quantity of information available to strategists, the quality and the quantity of information gathered and processed by the respondent companies appear to have very serious shortcomings. This area can be said to require adequate management attention. This is even more so in companies with formalized strategic planning systems and those which are already in the export market or contemplating to do so.

\section{Growth strategies and organizational structure}

Issues

After researching the historical development of 70 American companies, Alfred Chandler came up with the thesis that organizational structure follows company growth strategy. This means that at any particular time, a company's organization structure ' . . . is the result of the concantenation of several basic strategies' (Chandler, 1962). Alfred Chandler further observed that there is a time lag between the change in a company's growth strategy and the subsequent change in its organizational structure. The change in organizational structure is initiated when a company that has changed its growth strategy begins to experience administrative shortcomings which affects its effectiveness and efficiency.

Chandler's thesis on organizational structure falls within the contingency approach to organization structural designs. The contingency approach merely states that there is no one best organizational design: different organization structural designs are not equally effective (Lawrence \& Lorsch, 1967; Burns \&
Stalker, 1961; Duncan, 1978).

A lot of empirical research was stimulated by Chandler's findings. The first major research was conducted by Leonard Wrigley (1970). Using a sample of Fortune 500 companies, Wrigley distinguished between companies following a single product business; single dominant business (one product accounting for 70 to $95 \%$ of the firm's total sales); related business (more than $30 \%$ of firm's sales outside its main business); and the unrelated business (more than $30 \%$ of the firm's sales is outside its main business and this other business has little or no relation to the main business).

Wrigley's findings are as follows:

Single product or business firms organized around functional forms; hybrid forms of structure are used in dominant businesses which are organized functionally, and the diverse product/businesses are organized in divisional structures; and, companies that have diversified into related and unrelated businesses followed multi-divisional structures. In general these findings supported Chandler's thesis.

Similar studies have been conducted in other countries: in the U.K. (Channon, 1971), France (Pooley-Dyas, 1972) and in Germany (Thanheiser, 1972). In all these countries, especially between $1950-1970$, there was a steady decline in single and dominant businesses and an increase in the use of multi-divisional structures at the expense of Functional and Holding company structures. Further studies and theoretical constructs have added new dimensions to earlier considerations. Galbraith and Nathanson (1978) point out that diversification has to be combined with competitive conditions to lead to multi-divisional structures. Scott (1973) maintains that 'the divisional structure appears to be the most effective way to manage the strategy of diversification under highly competitive conditions'.

\section{Findings in Zimbabwe}

In this survey, Wrigley's (1970) classification of growth strategies was used. Table 8a shows structures with corresponding growth strategies. The conclusion that can be made is this: in general, the structure follows growth strategy. Single and single dominant businesses follow a functional structural form; the related businesses are equally divided between functional and divisional structural forms. A structural lag seems to obtain, given that $83 \%$ of the companies following a dominant business growth strategy reported their major industries to be highly competitive. Unrelated businesses, as expected, follow multi-divisional and holding company structural forms. All the respondent companies with unrelated business growth strategies are (or the significant number of their SBUs) in highly competitive industries.

Table $8 \mathrm{~b}$ shows responses from companies with formal strategic planning systems. Even in this category of respondent

Table 8a Strategy and structure (all respondent companies)

\begin{tabular}{|c|c|c|c|c|c|c|c|}
\hline \multirow[b]{2}{*}{ Growth strategy } & \multirow[b]{2}{*}{$\begin{array}{c}\text { Percentage following } \\
\text { strategy }\end{array}$} & \multirow[b]{2}{*}{$\begin{array}{l}\text { Functional } \\
\text { structure }\end{array}$} & \multirow[b]{2}{*}{$\begin{array}{l}\text { Multi-divisional } \\
\text { structure }\end{array}$} & \multirow[b]{2}{*}{$\begin{array}{l}\text { Holding company } \\
\text { structure }\end{array}$} & \multicolumn{3}{|c|}{ Industry competitiveness } \\
\hline & & & & & $\begin{array}{l}\text { No } \\
\text { comp. }\end{array}$ & $\begin{array}{l}\text { Low } \\
\text { comp. }\end{array}$ & $\begin{array}{l}\text { High } \\
\text { comp. }\end{array}$ \\
\hline & $\%$ & $\%$ & $\%$ & $\%$ & $\%$ & $\%_{0}$ & $\%$ \\
\hline Single business & 6 & 6 & $\overline{0}$ & 0 & 0 & 100 & 0 \\
\hline Dominant business & 39 & 28 & 11 & 0 & 14 & 14 & 71 \\
\hline Related business & 33 & 17 & 17 & 0 & 17 & 0 & 83 \\
\hline Unrelated business & 22 & 6 & 11 & 11 & 0 & 0 & 100 \\
\hline
\end{tabular}


Table 8b Strategy and structure (companies with formal strategic planning)

\begin{tabular}{|c|c|c|c|c|c|c|c|}
\hline Growth strategy & $\begin{array}{c}\text { Percentage following } \\
\text { strategy }\end{array}$ & $\begin{array}{l}\text { Functional } \\
\text { structure }\end{array}$ & $\begin{array}{l}\text { Multi-divisional } \\
\text { structure }\end{array}$ & $\begin{array}{l}\text { Holding company } \\
\text { structure }\end{array}$ & $\begin{array}{l}\text { No } \\
\text { comp. }\end{array}$ & $\begin{array}{l}\text { Low } \\
\text { comp. }\end{array}$ & $\begin{array}{l}\text { High } \\
\text { comp. }\end{array}$ \\
\hline & $\%$ & $\%$ & $\%$ & $\%$ & $\%$ & $\%$ & $\%$ \\
\hline Single business & 0 & 0 & 0 & 0 & 0 & 0 & 0 \\
\hline Dominant business & 30 & 30 & 0 & 0 & 0 & 0 & 100 \\
\hline Related business & 50 & 20 & 30 & 0 & 40 & 0 & 60 \\
\hline Unrelated business & 20 & 0 & 0 & 20 & 0 & 0 & 100 \\
\hline
\end{tabular}

companies it is demonstrated that structure follows strategy, with some structural lags within companies in related businesses growth strategies.

\section{Implications and lessons}

More general comments and lessons on growth strategy and structure will be given when dealing with strategy, structure, integration mechanism and performance. The point to be made at this juncture is that a stage-wise development of the company - with structure following the company's growth strategy - should not be simplistically interpreted. A fit between growth strategy and structure is crucial. Any new growth strategy has its administrative demands and problems which have to be solved through the redesign of the organizational structure. Any short-comings in the redesigning of the organization structure would render the new strategy ineffective and economic inefficiency would result.

In designing an organizational structure for any type of organization there is a need to fully understand the key characteristics of its environment and the demand such an environment makes on the organization, in terms of information processing and coordination (Duncan, 1978). Following the contingency approach to organizational design, Duncan (1978) suggests these steps: First, it is important to identify the company's internal environment (organization personnel component, organizational function and staff units components, organizational levels component, etc.) as well as its external environment (customer, suppliers, competitors, socio-political and technical components).

The second step involves the identification of the key characteristics of the environment along the simple/complex and static/dynamic dimensions.

The key general characteristics of a company's external environment

\begin{tabular}{lll}
\hline & Simple & Complex \\
\hline Static & $\begin{array}{l}\text { Low perceived } \\
\text { uncertainty }\end{array}$ & $\begin{array}{l}\text { Moderately low perceived } \\
\text { uncertainty }\end{array}$ \\
Dynamic & $\begin{array}{l}\text { Moderately high } \\
\text { perceived uncertainty }\end{array}$ & $\begin{array}{l}\text { High perceived } \\
\text { uncertainty }\end{array}$ \\
\hline
\end{tabular}

Source: Robert Duncan, 'What is the Right Organisation Structure?', Organisationat Dynamics, Winser 1979.

The simple-complex dimension is concerned with whether the factors in the environment considered for decision-making are few in number and similar or many in number and different. On the other hand, the static-dynamic dimension focuses on whether the factors of the environment remain the same over time or change with time.

Using the chart above, the static-simple combination leads to low perceived environmental uncertainty and, other things being equal, a functional organizational structure is suitable. However, a dynamic-complex combination leads to highly perceived environmental uncertainty and, accordingly, the creation of self-contained units to gather and process information from differentiated sub-environments is highly recommended: in organizational design terms, a multi-divisional or SBU structure is recommended. A matrix organization structure could be recommendable if, in addition to the dynamic-complex combination, the following conditions exist (Davis \& Lawrence, 1977):

(a) Outside pressure for dual focus, e.g. on product development and unique customer needs.

(b) Pressure for high information-processing capacity, and

(c) Pressure for shared resources i.e. 'pressure to achieve economies of scale in human terms and high performance in terms of both costs and benefits by fully utilizing scarce human resources and by meeting high quality standards' (Davis \& Lawrence, 1977).

The emphasis put forward by Duncan (1978) on the need to diagnose the key environmental characteristics before deciding on the organizational structure of the company is very important. It does not, however, provide all the issues that should be considered in designing a company's organizational structure. The following factors are either only implied in Duncan's (1978) analysis or are not considered: the current and/or the sought company strategy developed to meet preferred goal(s); patterns maintenance which represent the needs of the employees, in terms of job design preferences; and, the required levels of co-operation, given the nature of units interrelationships and the balancing of units and individual power within the company. This last consideration is implied in Duncan's (1978) description of internal environment.

The lesson from this discussion is that structure should not just be taken to follow growth strategy: the organizational structure also determines the efficacy of any company's strategy management system. Under changing environments, a company's adaptive capabilities, and hence its strategy formulation, implementation and monitoring capabilities are influenced by its organizational structure, which provide mechanisms to gather and process information from the environment. The organizational structure also provides requisite integration mechanisms of different company units.

Given the role played by the organizational structure it is crucial that organizational design should be taken as an integral part of strategy management. The prevailing practice, whereby strategy making and organizational design processes are done separately and by separate specialists, is inappropriate: it perpertuates the attributes of organizations as systems of limited adaptability.

\section{Integrating mechanism}

Issues

The distribution of organizational power and functions (responsibilities) within a company set-up at the same time creates coordination problems. Different companies create different types of integrating mechanisms to cope with general management problems having to do with interfunctional or 
inter-departmental coordination. Diversity in product/servicemarket-technology components of a company's environment leads to the decentralization of responsibility power centres. A company whose key environmental characteristics are represented by dynamic/complex combination tends to (or should) create highly differentiated structures or units, which are in a better position to deal with relatively unique subenvironments. Highly differentiated units create the need for higher forms of integration (Lawrence \& Lorsch, 1967). This need for integration is exarcebated in situations where the differentiated units are sequentially (one unit has to perform its functions before the next one can perform its own) and reciprocally (the output of unit $A$ becomes the input of unit B and the output B cycles back to become the input for unit A) interdependent.

Galbraith (1973) has identified, in order of complexity, the following integrating mechanisms:

(a) Hierarchy or referral system, where top managers act as key integrators.

(b) Rules/Procedures to deal with recurring structured problems.

(c) Goal setting by way of planning, e.g. budgeting and scheduling. Here exceptions to goals are either referred to the hierarchy or are resolved on the spot.

(d) Direct contact. Under this mechanism informal and spontaneous contacts between affected incumbents of units are encouraged.

(e) Cross-Functional/Units integrating roles or lateral relations. Under this category there are Interdepartmental Liaison Roles, Temporary Tasks Forces, Permanent Teams, Integrating Departments, etc.

In essence and consequence, the integrating roles of lateral relations are substitutes for general managers, spread across and down the organization structures. They also represent the means to implement diversification/decentralization strategies without reorganizing the company into product/service divisionalized structure (Covey \& Star, 1971).

\section{Findings in Zimbabwe}

In recording the composite responses on integrating mechanisms in Table 9a, ranks 1 to 4 are taken and the two highest rated mechanisms within each rank are given. Rules $(44 \%)$ and Goal setting $(28 \%)$ are the two highest rated in-

Table 9a Integrating mechanism (all respondent companies)

\begin{tabular}{|c|c|c|c|c|c|c|c|c|c|}
\hline \multirow[b]{2}{*}{$\begin{array}{l}\text { Mechanism } \\
\text { used }\end{array}$} & \multicolumn{9}{|c|}{ Percentage assigning ranks } \\
\hline & 1 & 2 & 3 & 4 & 5 & 6 & 7 & 8 & 9 \\
\hline & $\%$ & $\%$ & $\%$ & $\%$ & $\%$ & $\%$ & $\%$ & $\%$ & $\%$ \\
\hline Hierarchy & 44 & 11 & 11 & 17 & 11 & 0 & 0 & 0 & 0 \\
\hline Rules & 0 & 11 & 6 & 33 & 33 & 6 & 0 & 6 & 0 \\
\hline Goal setting & 28 & 11 & 33 & 17 & 6 & 0 & 6 & 0 & 0 \\
\hline Direct contact & 11 & 33 & 39 & 0 & 0 & 6 & 0 & 0 & 0 \\
\hline $\begin{array}{l}\text { Inter-depart- } \\
\text { mental liaison } \\
\text { roles }\end{array}$ & 11 & 28 & 6 & 17 & 28 & 6 & 0 & $\mathbf{0}$ & $\mathbf{0}$ \\
\hline $\begin{array}{l}\text { Temporary task } \\
\text { forces }\end{array}$ & 6 & 11 & 6 & 6 & 11 & 44 & 6 & 6 & $\mathbf{0}$ \\
\hline $\begin{array}{l}\text { Permanent } \\
\text { teams }\end{array}$ & 0 & 11 & 6 & 11 & 6 & 22 & 22 & 11 & 0 \\
\hline $\begin{array}{l}\text { Integrating roles } \\
\text { Integrating }\end{array}$ & 6 & 11 & 11 & 6 & 11 & 22 & 11 & 11 & 0 \\
\hline departments & 6 & 6 & 6 & 6 & 11 & 22 & 6 & 6 & 28 \\
\hline
\end{tabular}

Table 9b Integrating mechanism (respondents with formal planning)

\begin{tabular}{|c|c|c|c|c|c|c|c|c|c|}
\hline \multirow[b]{2}{*}{$\begin{array}{l}\text { Mechanism } \\
\text { used }\end{array}$} & \multicolumn{9}{|c|}{ Percentage Assigning Ranks } \\
\hline & 1 & 2 & 3 & 4 & 5 & 6 & 7 & 8 & 9 \\
\hline & $\%$ & $\%$ & $\%$ & $\%$ & $\%$ & $\%$ & $\%$ & $\%$ & $\%$ \\
\hline - Hierarchy & 30 & 10 & 20 & 20 & 10 & 0 & 0 & 0 & 0 \\
\hline - Rules & 0 & 10 & 10 & 30 & 40 & 0 & 0 & $\mathbf{0}$ & 0 \\
\hline - Goal setting & 40 & $\mathbf{0}$ & 40 & 20 & 0 & 0 & 0 & 0 & 0 \\
\hline - Direct contact & 20 & 30 & 30 & 0 & 0 & 0 & 0 & 0 & 0 \\
\hline $\begin{array}{l}\text { Inter-depart- } \\
\text { mental }\end{array}$ & 0 & 20 & 10 & 20 & 30 & 10 & 0 & 0 & 0 \\
\hline $\begin{array}{l}\text { Temporary } \\
\text { task forces }\end{array}$ & 10 & 10 & 10 & 10 & 10 & 30 & 10 & 0 & 0 \\
\hline $\begin{array}{l}\text { - Permanent } \\
\text { teams }\end{array}$ & 0 & 10 & 10 & 10 & 10 & 0 & 30 & 10 & 0 \\
\hline $\begin{array}{l}\text { - Integrating } \\
\text { roles }\end{array}$ & 10 & 0 & 10 & 10 & 10 & 0 & 10 & 20 & 0 \\
\hline $\begin{array}{l}\text { - Integrating } \\
\text { departments }\end{array}$ & 10 & 0 & 10 & 10 & 10 & 0 & 10 & 10 & 20 \\
\hline
\end{tabular}

tegrating mechanisms within rank 1 . Within rank 2 the two highest rated mechanisms are Direct contact (33\%) and Interdepartmental Liaisoning Roles (28\%). Direct Contact (39\%) and Goal Setting (33\%) are the leading integrating mechanism within rank 3 . The 4 th rank is occupied by Rules $(33 \%)$ and Hierarchy and Goal setting (17\% each).

The Responses on integrating mechanisms from companies having formal strategic planning systems are given in Table $9 \mathrm{~b}$. Goal Setting $(\mathbf{4 0 \%})$ and Direct Contact $(30 \%)$ are the two highest rated mechanisms within rank 1 . The two highest rated mechanisms within rank 2 are Direct Contact (30\%) and Interdepartmental Liaisoning Roles $(20 \%)$. Within rank 3, Goal Setting $(\mathbf{4 0 \%})$ and Direct Contact $(30 \%)$ mechanisms were given. Lastly, Rules (40\%) and Goal Setting (20\%) were given as the two highest rated integrating mechanisms in rank 4.

\section{Implications and lessons}

Companies with formal strategic planning systems seem to rely marginally more on 'organic' types of integrating mechanisms, like Goal Setting and Direct Contact as compared to companies with informal strategic planning systems.

Hierarchy, however, still plays a major role even in the former category of companies. This is so probably to meet the overall coordination of the diversified and decentralized units.

In general, the more complex integrating mechanisms are not utilized by the respondent companies. Without further research it is difficult to say whether this is a serious weakness or not. Taking all respondent companies, the 'mechanistic' types of integration feature prominently, although, even here, the 'organic' types are fairly represented.

Integrating mechanisms should be considered as part and parcel of the design of organization systems, which in turn are part of strategy-making processes and behaviour of companies. Not only should a company's organizational structure match its strategy, but its Integrating mechanisms should do so as well.

The more diverse the product/service-market-technology environment of a company's units are, the greater is the need to use 'organic' i.e. Cross-Functional Departmental Integrating mechanisms instead of 'mechanistic' ones, as represented by Hierarchy, Rules and Regulations.

The salient lesson out of the above discussion should be 
elevated above all else, and this is: the choice of integration mechanisms should not be allowed to be determined by chance or haphazardly. It should be considered as part of the means to enhance the strategic management capacity of any company. It should be systematically organized within any company's strategy management process.

\section{Compensation or reward systems}

\section{Issues}

The management of reward and sanctions systems in business organizations has remained an elusive area in general management. This is so, partially because the substantive issue of motivation of managers and other employees has not been successfully nailed down. Compensation or reward systems are taken here to encompass the entire process by which performance is measured, evaluated and rewarded. Punishments or sanctions only represent negative rewards.

When reward is tied to performance it tends to motivate higher performance (Lawler, 1971, 1977). Through compensation policies management engages in communication and in directing behaviour of different incumbents within the company. Any compensation system communicates the preferences of top-management and, accordingly, directs the behaviour of incumbents along preferred patterns. This happens whether management is conscious or unconscious of such effects.

Salter (1973) emphasized the linkage between compensation policy and strategy. Basically, any compensation policy should influence the behaviour of managers and other employees in such a way that the company's adaptive and integrative capabilities are enhanced.

A compensation policy should encourage managers not to sacrifice long-term strategic interests of the company in favour of the short-terms ones. Managers who have, in the interest of the company, to take risks should not only be encouraged to do so, but they should be correctly compensated. Where the co-operation between different units of a company is considered crucial, the compensation system should not only encourage cooperative behaviour, but should also reward it.

The success of different compensation packages is naturally influenced by what is measured to determine level of performance, the time horizon within which performance is measured and the level of acceptance by the incumbents of different positions within the company.

\section{Findings in Zimbabwe}

The findings on the compensation packages among all the respondent companies are shown in Table 10a, and the compensation packages of companies with formal strategic planning systems are shown in Table 10b. Viewed, in order of importance, the compensation packages of all the respondent companies are as follows: Salary $(78 \%)$ and Bonus $(28 \%)$, rank 1; Promotion (38\%), rank 2, and Fringe Benefits (50\%), rank 3. Companies with informal strategic planning systems emphasize marginally more group and organization-wide bonus schemes as compared to companies with formal strategic planning systems. These findings are shown in Tables $10 \mathrm{c}$ and $10 \mathrm{~d}$ respectively.

\section{Implications and lessons}

The overwhelming dominance of salary and promotion in the compensation packages of the respondent Zimbabwean companies ties compensation with positions or ranks occupied by individuals. Such compensation packages do not necessarily
Table 10a Compensation system (All responding companies)

\begin{tabular}{lrrrrrr}
\hline & \multicolumn{6}{c}{ Percentage assigning rank } \\
\cline { 2 - 8 } Type of compensation & 1 & 2 & 3 & 4 & 5 & 6 \\
\hline & $\%$ & $\%$ & $\%$ & $\%$ & $\%$ & $\%$ \\
\hline Discretional freedom & 11 & 0 & 6 & 22 & 33 & 6 \\
Fringe benefit & 0 & 11 & 50 & 17 & 6 & 0 \\
Salary & 78 & 17 & 6 & 0 & 0 & 0 \\
Stock option & 0 & 0 & 6 & 6 & 6 & 56 \\
Promotion & 11 & 39 & 17 & 22 & 0 & 6 \\
Bonus & 28 & 11 & 17 & 28 & 0 & 0 \\
\hline
\end{tabular}

Table 10b Compensation system (Respondent companies with formal planning)

\begin{tabular}{lrrrrrr}
\hline & \multicolumn{6}{c}{ Percentage assigning rank } \\
\cline { 2 - 8 } Type of compensation & 1 & 2 & 3 & 4 & 5 & 6 \\
\hline & $\%$ & $\%$ & $\%$ & $\%$ & $\%$ & $\%$ \\
\hline Discretional freedom & 10 & 0 & 10 & 20 & 20 & 10 \\
Fringe benefit & 0 & 20 & 30 & 10 & 10 & 0 \\
Salary & 70 & 20 & 10 & 0 & 0 & 0 \\
Stock options & 0 & 0 & 10 & 10 & 10 & 50 \\
Promotion & 20 & 30 & 10 & 20 & 0 & 10 \\
Bonus & 0 & 20 & 20 & 20 & 30 & 0 \\
\hline
\end{tabular}

Table 10c Levels of bonus schemes (All respondent companies)

\begin{tabular}{lccc}
\hline & \multicolumn{3}{c}{ Percentage assigning ranks } \\
\cline { 2 - 4 } Level & 1 & 2 & 3 \\
\hline & $\%$ & $\%$ & $\%$ \\
\cline { 2 - 4 } & 11 & 6 & 11 \\
Individual & 17 & 11 & 0 \\
Oroup & 39 & 6 & 0 \\
\hline
\end{tabular}

Table 10d Levels of bonus schemes (respondents with formal planning)

\begin{tabular}{lccc}
\hline & \multicolumn{3}{c}{ Percentage assigning ranks } \\
\cline { 2 - 4 } Level & 1 & 2 & 3 \\
\hline & $\%$ & $\%$ & $\%$ \\
\cline { 2 - 4 } & 20 & 0 & 10 \\
Individual & 10 & 20 & 0 \\
Oroup & 30 & 0 & 0 \\
\hline
\end{tabular}

motivate incumbents to higher performance within the positions they hold, except in so far as they might provide incentives to work harder in order to be promoted to higher salaried positions: consequently, the incentive value of such packages is dependent on the availability of slots to which incumbents are promotable.

A mix of bonus awards and stock options, reflecting relevant time horizons for policy executives can be used either to focus on short-run or long-run unit performance. These financial 
instruments should be combined with a correct mix of quantitative and qualitative measures of performance (Salter, 1973). Bonus awards in cash or stock could be used to reinforce risktaking behaviour.

Similarly bonus pools, say, on divisional performance, total corporate performance can be used to encourage interdivisional cooperation: the stock options can be used to link the interests of division/SBU personnel with the interests of the corporation as a whole and thus encourage healthy corporate-division/SBU relationships (Salter, 1973). The different levels in the hierarchy of complex organizations, the classification of Product/Divisions/SBUs with the consequent differentiated strategies help to highlight the difficulties associated with performance evaluation and rewarding of managers.

As has already been stated, the outcome of any incentive system in any company results in specific patterns of managerial behaviour. Ideally, managers of 'Stars' with more challenges, should receive predominantly individual incentives and 'cash cows' managers should receive relatively more group incentives since their tasks are more on the integrative mode (Lorange, 1980).

It is more often than not the case that the challenge associated with performance evaluation and compensation (incentive) systems is met, as a way of avoiding complexity, simplistically, via the overemphasis of short-term financial performance standards which foreclose meaningful strategic options and bring about incongruency between long-range corporate strategic goals and management behaviour. For instance, Return on Investment (ROI) is essentially a financial standard which becomes meaningless beyond a time horizon of five years. Furthermore, the longer the period at which returns are expected, the more variable and risky such returns are perceived by management. Strategic options like Research and Development (R \& D), extension of existing product lines, new product thrust, improved workers working conditions etc., are likely to be avoided by management which is evaluated strictly on financial criteria like ROI, earnings per share (EPS), etc.

The basic message about any compensation or reward system is that it should be tailored to enhance appropriate strategic behaviour of employees. A company should not just mimic what is done by other companies in its industry: it should design its compensation with its specific strategy in mind (Lorange, 1980). Where managers are expected to take a longterm strategic posture, with its associated risks, the compensation policy, including its performance measurement system and instruments, should not encourage short-term orientation.

The issues raised in the above paragraph are crucial in the Zimbabwean situation taking into account that $60 \%$ of the respondent companies gave a 'no opinion' response to the statements: 'The company has specified objectives for rewarding management at different organisational levels'.

\section{Objectives pursued by respondent companies}

\section{Issues}

Business companies as organizations are goal seeking entities. Goals represent preferred results or intended results which are pursued by purposeful entities called organizations. Cyert and March (1963), Simon (1964) and Gabb (1954) take the view that the existence of an organization is inconceivable without the need to satisfy some common objectives or goals.

Taking a general manager's strategic and leadership responsibilities, the company's goals or objectives provide essential guidelines to both strategic and operational decisions. For the goals to serve the purposes given above, they should be consistent both vertically (hierarchy of goals) and horizontally (goals of units at the same level of the organizational hierarchy); goals should be specific in their content and should indicate the level as well as the time period within which they are to be achieved. When goals possess such attributes they are said to be closed-end goals (Richard, 1978).

In strategic planning, the determination of goals or objectives has the following consequences: it influences the businesses within which a company is going to operate; it leads to certain product/service-market-technology choices; and, it influences the strategic behaviour of the members of the organization.

Objectives or goals are influenced by the company's need to respond appropriately to external demands, as well as to guide and influence internal behaviour of its members and units. As opposed to the marginalist economic school, companies have a vector or multiplicity of goals to satisfy at any given time. Of course, part of the multiple goals represent no more than just a means-ends-chain configuration. The multiplicity of stakeholders leads to the multiplicity of goals, with some goals actually acting as constraints to the attainment of the major ones.

In predominantly private enterprise economies the resultant impact made by companies in their society's economizing and quality of life needs is dependent on the modal goals or objectives they individually and severally pursue. This does not mean that the societal expectations and needs do not conflict with an individual company's preferences. It was within th above considerations that the respondent companies in Zir babwe were asked to rank a set of common business goals $i$ order of importance, as far as their preferences were concernex

\section{Findings in Zimbabwe}

Table 11 shows the two highest rated objectives within each rank moving from rank 1 to 5. The dominance of Profitability followed by Growth is obvious. Human Quality Of Life is rated in the 4th rank and Innovativeness tails at the end of the reported preferred goals of the respondent companies.

\section{Implications and lessons}

The questionnaire did not ask for the time horizon within which different goals are preferred and pursued. This means that the respondent companies were not asked to indicate whether their goal preferences were in the short or the long-term.

The follow-up interviews conducted by the researchers gave a strong impression that respondent companies were predominantly concerned with solvency. It is, therefore, possible that due to semantic imprecisions some companies perceptually equated profitability with solvency.

Profitability and growth (especially through the attainment of higher market shares) at any given time, are inconsistent goals, except that in the long-run they may be self-supporting. The pursuance of solvency objectives, is, with the exception of commercial banks, an anti-growth strategy. This objective is more relevant or consistent with harvesting or divesting strategies.

It is a commonplace, within business institutions, that growth - which is usually achieved via growth in market share - is initially purchased with heavy investments in fixed and working capital. This means that companies which are engaged in heavy investments as part of their growth strategic objectives would experience low profit margins in the short-to- 


\begin{tabular}{|c|c|c|c|c|c|c|c|c|c|c|c|}
\hline \multirow[b]{2}{*}{ Objectives } & \multicolumn{11}{|c|}{ Percentage assigning ranks } \\
\hline & 1 & 2 & 3 & 4 & 5 & 6 & 7 & 8 & 9 & 10 & 11 \\
\hline & $\%$ & $\%$ & $\%$ & $\%$ & $\%$ & $\%$ & $\%$ & $\%$ & $\%$ & $\%$ & $\%$ \\
\hline - Growth & 17 & 28 & $\overline{17}$ & 22 & 6 & 0 & 6 & 0 & 0 & 0 & 0 \\
\hline - Flexibility & 6 & 22 & 6 & 6 & 22 & 6 & 6 & 11 & 6 & 6 & $\mathbf{0}$ \\
\hline - Competitive leadership & 11 & 11 & 0 & 11 & 6 & 11 & 6 & 11 & 6 & 17 & $\mathbf{0}$ \\
\hline - Solvency & 17 & 17 & 17 & 6 & 17 & 6 & 17 & 0 & 0 & 0 & 0 \\
\hline - Innovativeness & 6 & 6 & 6 & 0 & 11 & 22 & 17 & 11 & 11 & 6 & $\mathbf{0}$ \\
\hline - Profitability & 61 & 17 & 17 & 6 & 0 & 0 & 0 & $\mathbf{0}$ & 0 & 0 & 0 \\
\hline - Market share & 0 & 11 & 6 & 17 & 11 & 11 & 0 & 0 & 11 & 11 & 11 \\
\hline - Internal social climate & 0 & 6 & 11 & 6 & 22 & 17 & 11 & 6 & 11 & 11 & 0 \\
\hline - External social responsiveness & 6 & 6 & $\mathbf{0}$ & 11 & 11 & 17 & 11 & 6 & 0 & 11 & 22 \\
\hline - Work satisfaction & 6 & 6 & 6 & 6 & 11 & 22 & 17 & 11 & 6 & 6 & 0 \\
\hline - Human quality of life improvement & 6 & 11 & 6 & 17 & 6 & 17 & 6 & 6 & 11 & 6 & 11 \\
\hline
\end{tabular}

medium-term.

At a macro or societal level, in any developing country, growth objectives are the most desirable. This is particularly so in the economic sectors that provide critical means for the raising of the quality of life for the greater majority.

Human and social 'responsiveness' goals received low ratings by responding Zimbabwean companies. This, by itself, does not suggest that Zimbabwean companies are socially irresponsible. It does no doubt mean, that in the vector of objectives, the human and social 'responsiveness' goals occupy a lower priority. And if they do so, strategies adopted and resources allocated in these companies are bound to accentuate the bias.

Business companies as open systems have to accommodate both internal and external demands on them: by so doing they are expected, from time to time, to alter the structure of their goals. It is 'either more goals and constraints are attended to or some goals sought rationally may need to be lowered (or even eliminated), so that resources can be devoted to fulfilling new expected results' (Richard, 1978).

Environmental changes to which companies should respond by way of restructuring their goals and strategies include competition, technology, social, legal and political changes.

Throughout the countries with free enterprise economic systems, business companies consider government regulations to be unfriendly or discouraging to private business interest (Jacoby, 1971). Compared with the American and British companies, the Zimbabwean companies are the least regulated.

What businessmen are fond of forgetting is that, in the final analysis, business institutions, like all types of instituted environments, derive their missions, goals, strategies, structures etc., from the normative (ideological) foundations of their societies. Changes in social values are reflected, through time, in the laws and regulations processed through the political system.

It is critically important that the Zimbabwean businessmen should accept the fact that the ideological (normative) foundations of this country have changed and/or are changing. From a strategic management point of view, managers of business institutions in this country should diagnose and prognose the dominant future thrust of the country's socio-politicoeconomic environments. With this information, appropriate missions, goals and strategies should be developed. The businessmen should find out what it takes to be successful and acceptable under the present and future societal conditions of Zimbabwe.

\section{Intensity of competition and characteristics of industries}

\section{Issues}

Structural analyses of industries within which companies operate play a significant role in strategy formulation or reformulation. Industry structure and behaviour determine or influence the competitive rules of the game and provide basic boundaries as to strategies potentially feasible to firms within a given industry. Furthermore, 'the structural features of industries determine the strength of competitive forces and hence industry profitability' (Porter, 1980).

The strengths and weaknesses of the competitive forces within an industry and the consequent ultimate potential returns on investment, profit margins, etc., are both endogenously and exogenously determined. Porter (1980) identifies six competitive forces which determine the ultimate potential profitability of the industry and its long-run return on investment. These forces are:

(a) The level of the bargaining power of suppliers to the industry.

(b) The potential entrants to the industry.

(c) The level of bargaining power of the buyers of the industry's products/services.

(d) The actual or potential substitute products/services to those currently produced by members of the industry.

(e) The intensity of rivalry of firms within the industry.

(f) The role played by government as the seller and/or buyer of the industry's products/services and the government's regulatory mechanisms.

In addition to the above competitive forces the stage at which the industry is, in terms of its life cycle, should be considered.

Each company occupies a particular 'ecological' niche within its industry: this 'ecological' niche should be defended or even expanded through the choice of different competitive strategies which have the desired impact, given the nature, strengths and weakness of the industry's competitive forces.

\section{Findings in Zimbabwe}

Table 12a shows the composite competitiveness of industries within which the respondent companies operate. Government regulations are perceived to be the highest factor affecting competitiveness of industries and consequently their potential profitability $\mathbf{( 7 8 \% )}$.

Threats of new entrants into served markets were reported as low $(\mathbf{7 8 \%})$, so were the threats from substitute products/ 
services $(50 \%)$. Sixty-one percent of reporting companies considered the bargaining power of buyers as low and the bargaining power of suppliers was perceived to be low by more companies than those who perceived it to be high $(33 \%)$.

As composite information, Table 12a does not capture fully competitive factors individual companies might be experiencing within their differentiated markets.

The characteristic modes of competition followed by the respondent companies are given in Table $12 \mathrm{~b}$. The five major competitive tools, in order of importance, used in the industries of the respondent companies are as follows: Product/Service quality, services (accompanying selling activities), prices, product/service differentiation and credit facilities.

The Industries Life Cycles and Composition of Sales are given in Table 12c. This table shows that $50 \%$ of the reporting companies are in growth industries, with $39 \%$ in saturated ones. On the average, companies operating in saturated industries have about $84 \%$ of their sales geared to local markets. On the other hand, $94 \%$ of sales, on the average, are geared to local markets by firms operating in growth industries.

\section{Implications and lessons}

The competitive forces within any industry go beyond the established industry competitors. Forces and factors acting outside an industry might operate to influence input costs and availability, as well as returns out of an industry's output. Government regulations further influence directly or indirectly the level of profitability of any given industry.

In Table 12b price, as a competitive tool, came number three. This means that, other things being equal, product/

Table 12a Composite competitiveness of industries

\begin{tabular}{lrcc} 
& \multicolumn{3}{c}{ Percentage responding } \\
\cline { 2 - 4 } Industry characteristics & None & Low & High \\
\hline - Rivalry among existing firms & 6 & 44 & 39 \\
- Threat of substitute product/services & 22 & 50 & 22 \\
- Bargaining power of buyers & 6 & 61 & 17 \\
- Bargaining power of suppliers & 6 & 44 & 33 \\
- Threats of new entrants into the market(s) & 0 & 78 & 11 \\
- Government(s) regulations & 0 & 11 & 78 \\
\hline
\end{tabular}

service quality and services accompanying selling activities are more important competitive tools than price. It might also mean that, since product/service quality and services accompanying sales are costly activities, better returns to companies can be achieved through higher pricing policies. But Experience or Scale Effects, in conjunction with other cost management programmes, might still not call for premium pricing policies.

Major serious competitive factors are reported low in the respondents' industries. The typical respondent company faces low threats from new entrants into served-markets and from substitute product(s)/Service(s). So is the bargaining power of the buyers and suppliers. In essence, this means that the typical respondent company is in a very low competitive market or industry. Such conditions tend to influence less innovative longterm strategies. These conditions may also afford companies an opportunity to earn higher profits than they would get in more competitive environments.

\section{Performance}

\section{issues}

A company's performance is measured in financial (economic) and non-financial denominations. Whether any level of performance is considered acceptable is purely dependent on managerial goals (taking into account both internal and external environmental opportunities and limitation), and the time horizon specified.

A number of researchers have tried to find out how the financial or economic performance of a company is related to its strategy and structure. Rumelt (1973) found that the type of diversification, and not the amount was related to economic

Table 12c Industries life cycles and sales composition

\begin{tabular}{lccc}
\hline & & \multicolumn{2}{c}{ Sales composition } \\
\cline { 3 - 4 } Life cycle & $\begin{array}{c}\text { Percentage of } \\
\text { companies }\end{array}$ & Average local & $\begin{array}{c}\text { Average } \\
\text { export }\end{array}$ \\
\hline Developmental & $\%$ & $\%$ & $\%$ \\
Growth & 6 & 95 & 5 \\
Saturation & 50 & 94 & 6 \\
Declining & 39 & 83,7 & 16,3 \\
\hline
\end{tabular}

Table 12b Modes of competition

\begin{tabular}{|c|c|c|c|c|c|c|c|c|c|c|c|c|}
\hline \multirow[b]{2}{*}{ Competitive tools } & \multicolumn{12}{|c|}{ Percentage assigning rank } \\
\hline & 1 & 2 & 3 & 4 & 5 & 6 & 7 & 8 & 9 & 10 & 11 & 12 \\
\hline & $\%$ & $\%$ & $\%$ & $\%$ & $\%$ & $\%$ & $\%$ & $\%$ & $\%$ & $\%$ & $\%$ & $\%$ \\
\hline & - & - & - & - & $\vec{n}$ & - & $\bar{u}$ & $\overline{-}$ & $\overline{-}$ & - & $\overline{0}$ & $\overline{0}$ \\
\hline - Prices & 17 & 22 & 6 & 17 & 11 & 11 & 11 & $\mathbf{0}$ & $\mathbf{0}$ & $\mathbf{0}$ & 0 & 0 \\
\hline - Product/service quality & 50 & 28 & 11 & 6 & 0 & 0 & 6 & 0 & 0 & $\mathbf{0}$ & 0 & 0 \\
\hline - Service (Acc, selling activities) & 28 & 11 & 28 & 6 & 6 & 0 & 0 & $\mathbf{0}$ & 6 & 6 & 6 & 0 \\
\hline - Product/brand identification & 6 & 6 & 11 & 28 & 11 & 6 & 0 & 17 & 0 & 6 & 6 & 0 \\
\hline - Full range of product/services offerings & 6 & 11 & 11 & 17 & 17 & 28 & 6 & 0 & 0 & $\mathbf{0}$ & 0 & 0 \\
\hline Promotion & 0 & 0 & 6 & 11 & 17 & 11 & 6 & 33 & 6 & $\mathbf{0}$ & 0 & 0 \\
\hline - Technological innovation & $\mathbf{0}$ & 6 & 17 & 6 & 17 & 17 & 11 & 11 & 6 & 11 & 0 & 0 \\
\hline - Credit facilities & 0 & 0 & 6 & 6 & 22 & 6 & 0 & 28 & 11 & 6 & 6 & 0 \\
\hline - Product/service differentiation & 0 & 0 & 17 & 6 & 17 & 11 & 6 & 17 & 11 & 11 & 0 & 0 \\
\hline - Channels of distribution & 11 & 0 & 17 & 11 & 11 & 11 & 6 & 11 & 11 & 6 & 6 & 0 \\
\hline - Broad product/service offering & 6 & 11 & 6 & 11 & 11 & 6 & 6 & 11 & 6 & 11 & 6 & 0 \\
\hline - Other (specify) & 0 & 0 & 0 & 0 & 0 & 0 & 0 & 0 & 0 & $\mathbf{0}$ & 0 & 0 \\
\hline
\end{tabular}


performance: controlled or constrained diversity, dominant and related businesses were found to be top performers in most of the economic performance criteria, such as return on equity, stability etc.

The explanation of the above findings given by Galbraith and Nathanson (1978) is that controlled or related diversification 'neither commits the organization to a single business nor stretches it across industries'. Entry into related businesses provides a company with an opportunity' 'to draw upon a common strength or a distinctive competence' (Galbraith \& Nathanson, 1978).

Using banks, insurance companies and hotels in U.K., Channon (1977) investigated the relationship between performance and structure within such business institutions. The findings were that single and related businesses were superior on a number of measures of growth and returns. On an overall comparison, the related businesses were marginally superior.

Multi-divisional firms showed high growth results for sales, assets, and earnings per share, while at the same time maintaining above average returns. Functional organizations had slightly higher returns and the holding companies were found to be the poorest performers.

According to Cable and Speer (1977), optimal organizational forms are multi-divisional, with separation of division and corporate interests based on time horizon, and functional organizations in single businesses. Non-optimal organizational forms are holding companies and multi-divisional companies 'with corporate of fices too involved in division activities, and diversified functional forms'.

Unconstrained diversification leads to unrelated business or conglomerately diversified corporations. A number of research findings have showed conglomerates to have lower returns on investment (ROI), profit margins etc., than the related and dominant businesses. The strength of conglomerately diversified corporations are in their minimization of risk as represented by the lower variability of returns.

\section{Findings in Zimbabwe}

In Table 13 five-year averages in different performance measures, for all companies within given growth strategycategories, are shown. The different performance measures are: return on investment, return on net assets, profit margins and asset turnover. Related business companies outperform those with unrelated businesses in all performance criteria except on returns on net assets. Risk in each performance criterion and for each group of companies is measured by the standard deviation and the coefficient of variations - which measure risk per unit of return or per whatever performance criterion.

The unrelated business companies minimize risk in all the performance criteria except on return on investment where they experience the same risk as those companies in related businesses.

A further comparison can be made between single and dominant business companies on one hand, and those with related and unrelated businesses on the other hand. Single and dominant business companies are completely outclassed in all performance categories except profit margins. The same results obtain in risk minimization, except that variability in asset turnover is lower for single and dominant businesses as compared to related and unrelated businesses. This exception is due to an abnormally high asset turnover performance in one of the companies with related businesses.

\section{Implications and lessons}

Most of the research results in strategy-structure match have failed to show conclusively that the 'fit' between strategy and structure is a significant predictor of economic or financial performance of a company.

The problem of linking performance with any of the independent variables (strategy, structure, compensation, integration mechanisms, etc.) centres around the direction of causation, as well as (like in a step-wise regression process) the level of contribution of each independent variable to the level of the criterion variable. Relaxing the additivity assumptions with respect to the behaviour of independent variables, one has also to determine the interaction effect of all the independent variables.

Child (1972) provides another caveat: performance (in whatever form) should not be taken as just a variable dependent on other factors. It also, in its own right, acts as an independent variable - as in a situation where poor performance causes management to centralize decision-making in the company. The effects of such centralization of decision-making would affect strategic planning processes and ultimately the company's performance. Here the direction of causation is different from the one usually associated with strategy-structure etc., performance relationships.

There are also factors outside strategy-structure etc., which affect performance. Performance is a result of a vast number of combinatorial interactions between forces within management control and those outside it. For instance, Negandhi and Reiman (1976) found that although decentralization is related to effectiveness under all conditions, the strength of the relation varies with the competitiveness of industries or markets.

The product/market life cycles of different companies can also result in different levels of performance, other factors remaining constant.

There are also serious limitations associated with research

Table 13 Relative financial performance (ratios)

\begin{tabular}{|c|c|c|c|c|c|c|c|c|c|c|c|c|c|}
\hline & \multirow{2}{*}{$\begin{array}{l}\text { Percentage } \\
\text { represented }\end{array}$} & \multicolumn{3}{|c|}{ ROI } & \multicolumn{3}{|c|}{ RNA } & \multicolumn{3}{|c|}{ Profit margin } & \multicolumn{3}{|c|}{ Asset Turnover } \\
\hline & & $\bar{x}$ & S.D. & C.V. ${ }^{\mathrm{a}}$ & $\mathbf{X}$ & S.D. & C.v. & $\mathrm{X}$ & S.D. & C.V. & $\overline{\mathrm{X}}$ & S.D. & C.V. \\
\hline Related businesses & 44 & 12,51 & 3,29 & 0,26 & 11,93 & 3,71 & 0,31 & 15,78 & 3,55 & 0,22 & 21,55 & 3,70 & 0,17 \\
\hline $\begin{array}{l}\text { Unrelated businesses } \\
\text { Both related \& unrelated }\end{array}$ & 22 & 10,69 & 2,78 & 0,26 & 13,69 & 2,76 & 0,20 & 6,78 & 1,06 & 0,16 & 11,48 & 0,16 & 0,11 \\
\hline $\begin{array}{l}\text { huvinesses } \\
\text { Singte \& dominant }\end{array}$ & 61 & 11,73 & 3,16 & 0,27 & 12,68 & 3,30 & 0,26 & 11,92 & 2,48 & 0,21 & 12,94 & 2,18 & 0,17 \\
\hline businesses & 39 & 6,30 & 2,06 & 0,33 & 11,15 & 4,29 & 0,38 & 17,38 & 6,38 & 0,37 & 0,90 & 0,13 & 0,14 \\
\hline
\end{tabular}


aimed at determining the effect of, say, strategy-structurecompensation match or 'fit' on a company's performance. In the research that has so far been in the forefront, strategy is simplistically described: strategy has been described in terms of level of diversification - hence the description of single, single-dominant businesses etc. In determining and evaluating a company's strategy one should go beyond product(s) choices, with markets simply remaining implied. Different companies may have similar breadth and depth of product lines, but differ in the choice of markets served and/or at the level of entry into the markets. Such differences would bring about different market effectiveness and efficiency.

Furthermore, in dealing with a company's strategy one has to determine and evaluate the chosen modes of competition. Companies with the same breadth and depth of product lines might differ in the combination of competitive tools such as: price, distribution, credit, deployment and responsibilities of the sales force, promotional mix, technological innovation, etc. Differences in the chosen competitive tools are also bound to lead to differential market outcomes.

Lastly, the pattern and level of resource allocation among different units within a company affect the strategic effectiveness of any company. This, therefore, means that companies which are similar in all other respects, but differ in the patterns and levels of resource allocation among different units would achieve different performance outcomes.

What is even more important to realize is that there can be no substantial change in structure (to match changes in the company's domain or scope strategy) without compensating and reinforcing changes in organizational processes, compensation/sanction systems and the people (motivation, ability, skills, etc.). This comprehensive approach to structure, processes, systems, etc., underlines the fact that any company's performance outcome is a function of its product/servicemarket strategy, with the intervening interacting variables such as tasks, structure, people, reward system, information and decision processes (Galbraith \& Nathanson, 1978). The research on how the strategy-structure match affects performance has not taken all the important variables into account. This is, no doubt, a difficult task, what needs to be done is, as in a stepwise regression process, to identify variables which significantly help to predict performance; the rest can be rejected.

To come up with reasonable and acceptable results of factors positively and negatively related to performance, large samples, longitudinal and disaggregated data and sophisticated timephased econometric techniques are required.

The inconclusiveness of results from research done on factors affecting financial or economic performance should not be taken to mean that this matter does not deserve serious management attention.
It should be appreciated that economic and non-economic performance of any company are a result of fit between factors internal to the company and their appropriateness to factors external to it.

The fit between the internal choices and external environmental factors is a dynamic one. Companies experience quasidynamic equilibrium states. For instance, taking internal choices only, any ' . . move from one strategy to another requires disengaging, realignment and a reconnecting of all these (structure, rewards, etc.) factors' (Galbraith \& Nathanson, 1978).

\section{New product introduction and technological innova- tions}

Issues

The future of any business, especially in competitive and changing market conditions, is determined by its innovativeness. Surrogates for such innovativeness are represented by the rate and quality of new product(s)/service(s) introduced and the rate and quality of new technology (tools, equipment, production techniques and processes, skills, etc.) introduced within a certain span of time. From a societal point of view, the quality of life enjoyed by members of society is dependent on the rate and quality of product(s)/service(s) made available by economic institutions. The commensurate wherewithal available to have access to such means of consumption are also important.

\section{Findings in Zimbabwe}

The researcher's interest in this area was limited to gaining some impressions on how strategy-structure relationships affected new products and new technological innovations. These findings are shown in Table 14.

Companies in unrelated businesses introduced 50 and 100 new products within the last 5 and 10 years respectively. This innovative performance was followed by companies in related businesses. Companies in dominant businesses are the least innovative in new product introduction.

The results on innovation as shown in Table 14 should be cautiously interpreted. Companies in unrelated businesses usually come about through mergers and acquisitions. Products of the acquired company are new to the acquiring company. This transfer does not satisfy the strict definition of new product development and introduction. Furthermore, there is a threshold problem - at what level does product improvement pass into a new product domain, and, from whose point of view - a consumer/user or producer?

On the number of times new technology has been introduced within the last 5 and 10 years, only related businesses reported new technology introduction. Even here the threshold problem

Table 14 Innovativeness (all respondent companies)

\begin{tabular}{|c|c|c|c|c|c|c|c|c|}
\hline \multirow[b]{2}{*}{ Growth strategy } & \multirow[b]{2}{*}{$\begin{array}{l}\text { Percentage } \\
\text { following }\end{array}$} & \multirow[b]{2}{*}{ Functional } & \multirow[b]{2}{*}{ Multi-divisional } & \multirow[b]{2}{*}{ Holding Co. } & \multicolumn{2}{|c|}{$\begin{array}{c}\text { Number of new } \\
\text { products } \\
\text { introduced }\end{array}$} & \multirow{2}{*}{$\begin{array}{c}\begin{array}{c}\text { Number } \\
\text { of new } \\
\text { tech. }\end{array} \\
\text { Last } \\
5 \text { Yrs }\end{array}$} & \multirow{2}{*}{$\begin{array}{c}\begin{array}{c}\text { Times } \\
\text { intro- } \\
\text { duced }\end{array} \\
\text { Last } \\
10 \mathrm{Yrs}\end{array}$} \\
\hline & & & & & $\begin{array}{l}\text { Last } \\
5 \text { Yrs }\end{array}$ & $\begin{array}{l}\text { Last } \\
10 \mathrm{Yrs}\end{array}$ & & \\
\hline & $\%$ & $\%$ & & & & & & \\
\hline Single pro. business & $\overline{6}$ & $\overline{6}$ & 0 & 0 & 0 & 0 & 0 & 0 \\
\hline Dominant business & 35 & 24 & 12 & 0 & 5 & 6 & 0 & $\mathbf{0}$ \\
\hline Related pro. business & 35 & 18 & 18 & 0 & 12 & 17 & 2 & 2 \\
\hline Unrelated business & 24 & 6 & 6 & 12 & 50 & 100 & 0 & $\mathbf{0}$ \\
\hline
\end{tabular}


exists as is the case with product improvement. It is worth noting that most of the respondent companies do not have formally organized Research and Development units.

\section{Implications and lessons}

One cannot make a conclusive statement as to the level of innovativeness of companies in Zimbabwe from the responses of those which participated. Proliferation of new products, per se, is not a measure of effectiveness. But product improvement, new product development and introduction (with better quality/reliability, with more functional and consumption values to society) are undoubtedly indices of business innovativeness.

New product development and introduction require high Research and Development ( $R$ \& D) capabilities. The R \& D efforts should be geared to meet market needs as defined by market research and should be managed as an integral part of an effective new product development programme within the company.

Technological innovation should be geared to cost reduction through the simplification of production processes and product design. It should also be geared to play a major role in new product development and/or in the improvement of the functional and consumption value of old products.

\section{Strategic planning process evaluation}

\section{Issues}

The strategic planning process as a concrete aspect of the corporate strategic management system is viewed differently by different persons. There are, for the purposes of this report, two areas to be covered under the above sub-topic: the evaluation of the strategic process in general, as perceived by different practitioners; the evaluation of the strategic planning process in terms of the necessary attributes it should have in order to be effective.

Practitioners in strategic planning as well as academics can be generally divided into two groups in terms of their approach to or perception of strategic planning processes. The first group views the strategic planning process in rational - normative terms, while the second group takes a behavioural viewpoint where strategic planning is taken as a social, (or as a political) process.

The rational-normative group represents the classical decision-making theories with emphases in rationality of human action, objectivity and unlimited computational and cognitive powers of human beings. 'The micro-economic assumption of a unitary voice within the firm has predominated: organizational preferences are assumed to be known and consistent, cause-effect relationships fairly well- understood and information availability sufficient to tackle most issues' (Fahey \& Narayanan 1980).

The second group views decision-making as an interpersonal process and, accordingly, as a social or a political process. This process ranges from a situation where one or more decision alternatives are unacceptable or uncertain for one or more members of a group, to a situation whereby interests of individuals outside the organization have to be accommodated. Goals of outside constituencies are not usually well-known or well crystallized. Prediction and Planning based on objective information is not usually possible: decision-making under such a situation involves step or incremental responses to problems as they arise (Quinn, 1980; Mintzberg, 1978; Simon 1957; March \& Simon, 1958). Organizations under this model tend to 'muddle-through' undefined and unpredicted decision- making conditions (Lindblom, 1959). Decision-making processes under the conditions specified by the second group are characterized by bargaining and politicking among coalition members; between the coalition and outside stakeholders.

\section{Findings in Zimbabwe}

The evaluation of formalized strategic planning systems by the participating companies is given in Table 15. Qualitative factors in strategic decision-making are perceived to play a major role rather than the analytically quantifiable ones, which come second in perceived importance. The rationality of strategic decision-making processes is perceived to be more characteristic of such processes than the political view of strategic decision-making processes.

\section{Implications and lessons}

In interpreting the ranking of the strategic planning evaluative statements as given in Table 15 one has to remember that managers normally do not want their behaviours to be perceived as being politically motivated. Managers would like to be

Table 15 Evaluating formalized strategic planning system (respondent companies with formal planning).

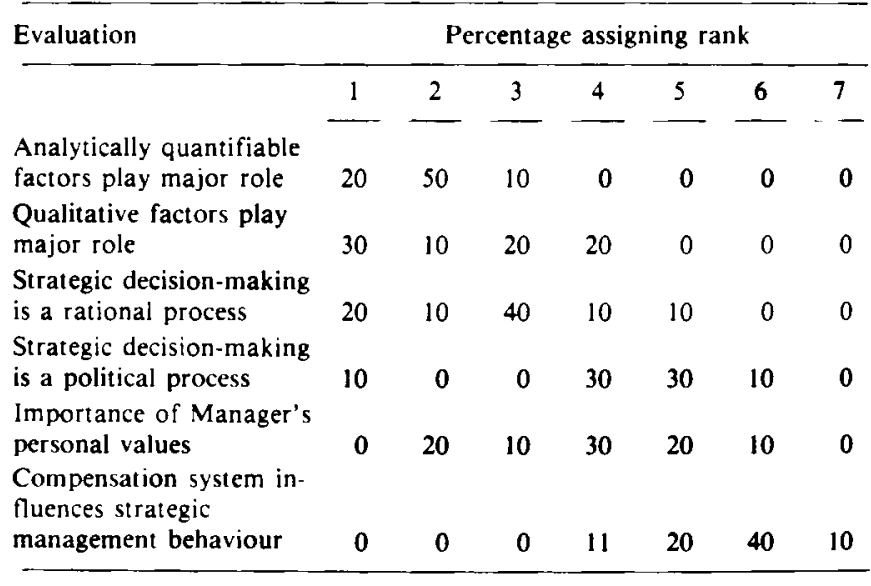

perceived as 'rational' beings; and as such they prefer to be taken as being motivated by rational and objectively determined goals. The phoenix of a rational entrepreneur, whose accumulation of wealth, was due to 'absolute' rationality in the management of economic resources influences managers to perceive themselves within that legend.

There is no running away from the fact that organizations like companies are basically political entities: They represent coalitions of interests and demands emanating from within and outside their boundaries (Thomson, 1967; Mintzberg, 1978). Organization goals, policies and strategies are differentially ranked by different members of the coalition of constituencies. 'Under these conditions, organizations can be viewed as loose structures of interests and demands, competing for organizational attention and resources and resulting in conflicts which are never completely resolved' (Fahey \& Narayanan, 1980).

Strategic decisions are invariably associated with the allocation and/or reallocation of scarce company resources (leading to well-known 'budget-battles' in private and public institutions); affect the power positions of company units (division, SBUs, function, etc.) and consequently the power and influence of incumbents of positions within such units; strategic decisions are opportunity and risk taking processes which are nor- 
mally calibrated in personal, coalition, subgroups, etc., terms. All these factors influence political behaviour of participants in the strategic decision process, as individual units vie for power, influence, amount of resources to be allocated, etc. This situation is not something to be ashamed of - it is a natural phenomenon that needs to be managed so as to minimize its dysfunctional effects.

\section{Conclusion}

A number of issues of strategic importance have been covered in this report. It was shown that the move from informal to formal strategic planning systems is precipitated by certain events acting in combination with some favourable preconditions existing within companies. The formalization of strategic planning is usually resisted, for various reasons, by individuals within a company.

The planning responsibilities appeared to be well distributed among the companies to effect high levels of participation on strategic decision-making processes. But the quality and quantity of information available for use in strategic planning processes appear to be inadequate. This limitation undermines the effective use of analytical tools currently utilized in strategy formulation and evaluation processes.

Alfred Chandler's thesis on structures following growth strategies of companies was generally confirmed although some structural lags were also shown to exist. The integration mechanisms are well distributed along the 'organic'-'mechanistic' continuum, although the 'mechanistic' ones marginally dominate.

Salary and promotion still play a major role in the compensation packages of the respondent companies. Most of the participating companies have no specified objectives for rewarding management at different organizational levels.

On objectives pursued by all participating companies, profitability dominated, followed by growth. The time horizon within which such objectives are preferred and pursued was not indicated as it was not asked for.

Most of the respondent companies operate in quasi-monopolistic markets, although in a number of multi-products and multi-division companies some products and/or divisions operate in relatively highly competitive markets or industries. Government regulations are perceived to be important factors in affecting the competitiveness of industries and, consequently, in affecting their profitability and returns on investments.

Companies with related businesses outperformed in financial terms those in unrelated businesses. Those with related and unrelated businesses taken together outperformed companies in the single-dominant businesses.

The variability of returns as a measure of risk is significantly minimized by companies in unrelated businesses. Companies with related and unrelated businesses taken together minimized risk better than those in single and dominant businesses.

Technological innovation appears to be very limited and this is likely to be affecting new product development and cost reduction programmes in the production processes.

By and large, most of the participating companies perceive strategic planning processes in accordance with the rationalnormative model of decision-making.

\section{Areas for further research}

There is a need to vigorously determine the factors that can reasonably predict financial and non-financial performance of companies in Zimbabwe. Larger samples are required to look at the strategies pursued, organizational structures, job designs, human resources utilization, competitive environments, etc., in order to determine the level of contribution of each to both the financial and non-financial performance of the Zimbabwean companies.

It is also of interest to research on how the Zimbabwean managers are managing change within their companies as dictated by changes at the socio-political arena. As to how different change strategies affect or are likely to affect the performance of companies, operating in Zimbabwe within the next 5 to 10 years is obviously a matter of interest both to private businesses and to the government.

Technology choices and technology development capabilities within the country's companies deserve special research attention, as do the factors that affect the quantity and quality of skills within different companies and industries.

\section{Acknowledgements}

The successful completion of this exercise was made possibly by a number of representatives of companies within Zimbabwe. Some of these helpful people participated during the pilottesting of the questionnaire, as well as in filling-in and returning the final questionnaires to the researcher. Due to confidentiality requirements, the names of such persons and the organizations they represented cannot be given.

The researcher is also grateful to the research Board of the University of Zimbabwe which financed the entire exercise.

Lastly, the researcher extends his gratitude to two third-year Business Studies students, namely Miss Tracy Mugambiwa and Mr Kenneth Mushoriwa, who meticulously helped in the compilation and collating of responses from individual questionnaires.

\section{Reierences}

Abell D.F. \& Hammond J.S. 1979. Strategic Market Planning. New Jersey: Prentice-Hall.

Andrews K.R. 1971. The Concept Corporate Strategy. Homewood: Dow Jones-Irwin.

Ansoff I.H. 1980. Strategic Issue Management. Strategic Manage. J, vol. 1.

Burns, T. \& Stalker G.M. 1961. The Management of Innovation. London: Tavistock Publications.

Cable, J. \& Steer P. Feb. 1977. 'On the Industrial Organisation and Profitability of large UK Companies,' unpublished working paper, Liverpool Polytechnic.

Chandler, A.D. 1962. Strategy and Structure. Cambridge, Massachussets: MIT Press.

Channon, D. 1973. The Strategy and Structure of British Enterprise. London: MacMillan \& Co.

Chevailier, M. 1972. The Strategy Spectre. Behind Your Market Share. Eur. Bus. Summer.

Child, J. 1974. What determines Organisation: The Universal versus the IL-All-Depends? Organ. Dyn. Summer, vol. 3, no. 1.

Corey, R. \& Star S. 1971. Organisation Strategy. Boston: Division of Research, Harvard Business School.

Cyert, R. \& March J. 1963. The Behovioural Theory of the Firm. Englewood Cliff, N J: Prentice-Hall.

Davis, S.M., \& Lawrence P.R. 1977. Matrix. Reading: AddisonWesley Publishing Co.

Duncan, R. Sept. 1972. Characteristics of Organisational Environments and Perceived Environmental Uncertainty. Admin Sci. $Q$.

Duncan, R. 1979. 'What is the right organization structure? Decision tree analysis provides the answer? Organ. Dyn. Winter.

Fahey L. \& Narayanan V.K. April 1979. The Micro-Politics of Strategy Formulation. (Paper presented at Mid-West Academy of Management meeting. Cincinnati.)

Galbraith, J. 1973. Designing Complex Organisations. California: Addison-Wesley Publishing Inc.

Galbraith, J.R. \& Nathanson, A. 1978. Strategy Implementation: The Role of Structure and Process. New York: West Publishing Co. 
Hall, W.K. Feb., 1978. 'SBUs: Hot, New Topic in the Management of Diversification'. Bus. Hor.

Hussey, D.E. 1979. Introducing Corporate Planning. 2nd Edition. Oxford: Pergamon Press.

King, W.R. \& Cleland D.I. Feb. 1977. Information for more Effective Strategic Planning. Long-range Planning, vol. 10.

Lawler, E. 1971. Pay and Organisational Effectiveness: $A$ Psychological View. New York: McGraw-Hill.

Lawler E. 1977. Reward Systems, in Hackman \& Suttles (Eds). Improving Life at Work. Santa Monica, California: Goodyear Publishing.

Lawrence, P. \& Lorsch J. 1967. Organisation and Environment. Boston: Division of Research, Harvard Business School.

Lindblom, C.E. 1959. The Science of Muddling Through. Public Admin. Rev., Journal of the American Society for Public Administration, vol. 19.

Lorange, P. 1980. Corporate Planning. New Jersey: Prentice-Hall.

Mintzberg H., Duru R. \& Andre T. June 1976. The Structure of 'Unstructured' Decision Processes. Admin. Sci. Q., vol. 21.

Naylor, T.H. 1979. Corporate Planning Models. Reading: AddisonWesley Publishing Co.

Negadhi, A. \& Reinmann B. 1976. 'Organisation Structure and Effectiveness: A Canonical Analysis', in Kilman, Pondy \& Slevin (Eds).
The Management of Organisation Design, vol. 11. Amsterdam: Elservier North Holland,

Porter M.E. 1980. Competitive Strategy: Techniques for Analysing Industries and Competitors. New York: The Free Press.

Quinn, J.B. 1980. Strategies For Change: Logical Incrementalism. Homewood, Illinois: Irwin.

Richard M.P. 1978. Organisational Goal Structures. New York: West Publishing Company.

Rumelt, R. 1974. Strategy, Structure and Economic Performance. Boston: Division of Research, Harv. Business School.

Salter, M. 1970. Tailor Incentive Compensation to Strategy . HBR 51.

Scott, B.R. 1973. 'The Industrial State: Old Myths and New Realities'. HBR 51.

Steiner, G.E. 1979. Strategic Planning. New York: The Free Press. Thomson, A.A. \& Strickland A.J. 1980. Strategy Formulation and Implementation.

Thomson J.P. Summer 1967. Organisation in Action. New York: McGraw-Hill.

Wheelright, S.C. \& Banks R.L. 1979. Involving operating managers in Planning Process Evolution. Sloan Manage. Rev.

Wrigley L. 1970. Divisional Autonomy and Diversification, unpublıshed Doctoral Dissertation. Havard Business School. 